Review

\title{
Marine-Derived Angiogenesis Inhibitors for Cancer Therapy
}

\section{Ying-Qing Wang and Ze-Hong Miao *}

Division of Antitumor Pharmacology, State Key Laboratory of Drug Research, Shanghai Institute of Materia Medica, Chinese Academy of Sciences, 555 Zu Chong Zhi Road, Zhangjiang Hi-Tech Park, Shanghai 201203, China; E-Mail: yqwang@jding.dhs.org

* Author to whom correspondence should be addressed; E-Mail: zhmiao@simm.ac.cn; Tel./Fax: +86-21-50806820.

Received: 4 February 2013; in revised form: 25 February 2013 / Accepted: 1 March 2013 / Published: 15 March 2013

\begin{abstract}
Angiogenesis inhibitors have been successfully used for cancer therapy in the clinic. Many marine-derived natural products and their analogues have been reported to show antiangiogenic activities. Compared with the drugs in the clinic, these agents display interesting characteristics, including diverse sources, unique chemical structures, special modes of action, and distinct activity and toxicity profiles. This review will first provide an overview of the current marine-derived angiogenesis inhibitors based on their primary targets and/or mechanisms of action. Then, the marine-derived antiangiogenic protein kinase inhibitors will be focused on. And finally, the clinical trials of the marine-derived antiangiogenic agents will be discussed, with special emphasis on their application potentials, problems and possible coping strategies in their future development as anticancer drugs.
\end{abstract}

Keywords: marine natural products; angiogenesis; protein kinase; cancer therapy

\section{Introduction}

Angiogenesis not only plays an important role in physiological processes but is also involved in initiating and promoting several diseases such as cancer. As a hallmark of cancer [1], angiogenesis is considered as a powerful target to suppress tumor growth and metastasis. Several target proteins that are crucial for angiogenesis have been identified, i.e., vascular endothelial growth factor (VEGFR)-related kinases [2], matrix metalloproteinases (MMPs) [3], methionine aminopeptidase (MetAP) [4], actin, 
microtubule [5], and histone deacetylases (HDACs) [6]. Using small molecules that inhibit angiogenesis-associated proteins has become a successful strategy for cancer therapy in the clinic [7].

Marine-derived natural products have been known for their huge diversity of chemical structures, and their unique structures are frequently associated with special mechanisms of action by which they may elicit unexpected biological activities. Therefore, increasing attention has been paid to the development of marine-derived anticancer drugs. Till now, two of four approved marine-derived drugs are anticancer drugs, i.e., cytarabine [1969, approved by the Food and Drug Administration (FDA)] and ecteinascidin 743 (2007, approved by the European Agency for the Evaluation of Medicinal Products) [8,9]. As an important type of anticancer drugs, in recent years, marine-derived antiangiogenic agents have been widely investigated. At least 43 marine-derived natural products and their derivatives have been reported to display antiangiogenic activities, mediated by distinct or unknown molecular mechanisms. Among them, 10 entered either phase I, phase II or phase III clinical trials for cancer therapy. This review first provides an overview of these agents based on their potential distinct mechanisms/molecular targets, and then focuses on those that modulate kinase activities and those in clinical trials.

\section{An Overview of Marine-Derived Antiangiogenic Agents}

The reported 43 marine-derived antiangiogenic agents have various sources (Figures 1-4). More than half of them (24) come from marine animals, including sponge, sea cucumber, bryozoan, tunicate, sea hare, and shark. Among them, 17 are from different sponges. The second important source is marine microorganisms including fungi, bacteria and actinomycetes that produce 11 agents. Marine phytoplanktons (mainly different algae) are their third largest source, from which 8 natural antiangiogenic agents come. This feature suggests that as a source of natural antiangiogenic agents, marine animals, especially sponges, have absorbed the most attention in the related investigation. It also shows that there are still tremendous opportunities to find new types of antiangiogenic agents from the ocean because the above-listed explored sources are just a small fraction of the marine resource that contains nearly $80 \%$ of all kinds of life on the Earth [9].

The great diversity of their chemical structures, partially due to their distinct sources, further characterizes those agents (Figures 1-4). Among them, there are six saccharides (JG3, MdOS, native fucoidan, oversulfation of fucoidon, SargA and sulfated galactan), six macrocycles (bastadin 6, bryostatin-1, cytochalasin $\mathrm{E}$, dihydromotuporamine $\mathrm{C}$, laulimalide and spongistatin 1), five terpenes (cortistatin A, isomarabarican triterpenes, laurenditerpenol, pyripyropene A and squalamine), four alkaloids (ageladine A, fascaplysin, plinabulin and streptochlorin), four pyrones (hypochromin A, hypochromin B, puupehenone and SC2051), four peptides (azumamides, plitidepsin, soblidotin and somocystinamide A), two saponins (philinopside A and philinopside E), two xanthones (anomalin A and norlichexanthone), nine of other structures (aeroplysinin-1, fumagillin, LAF389, marizomib, neolamellarin, panobinostat, psammaplin A, streptopyrrolidine and TNP-470), and one extract from shark cartilage (neovastat). The diverse chemical structures confer distinct activities and mechanisms of action to those agents. Here we roughly divide the reported 43 marine-derived antiangiogenic agents into five classes: Protein kinase modulators, cytoskeleton disturbing agents, HDAC inhibitors, MetAP inhibitors and others, based on their mechanisms/primary targets. 
Figure 1. Structures and sources of macrocycles and saccharides. JG3, $\mathrm{R}_{1}=\mathrm{SO}_{3} \mathrm{Na}$, $\mathrm{R}_{2}=\mathrm{H}$ or $\mathrm{SO}_{3} \mathrm{Na}, n=3-9$; MdOS, $\mathrm{R}_{1}=\mathrm{SO}_{3} \mathrm{Na}, \mathrm{R}_{2}=\mathrm{H}$ or $\mathrm{SO}_{3} \mathrm{Na}, \mathrm{R}_{3}=\mathrm{CH}_{2} \mathrm{CH}(\mathrm{OH}) \mathrm{CH}_{3}$ or $\mathrm{Na}, n=2-8$.<smiles></smiles>

(Sponge Lanthella basta)

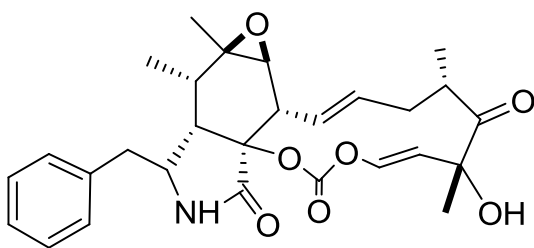

Cytochalasin E (Fungus Arthrinium sacchari)

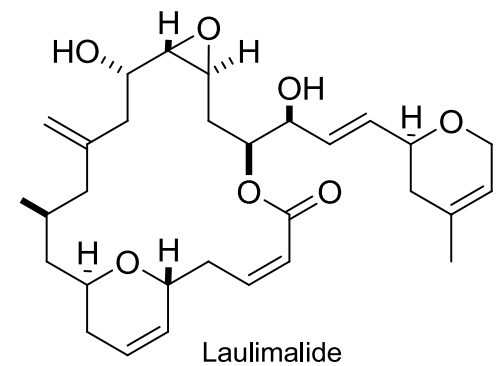

(Sponge Cacospongia mycofijiensis)

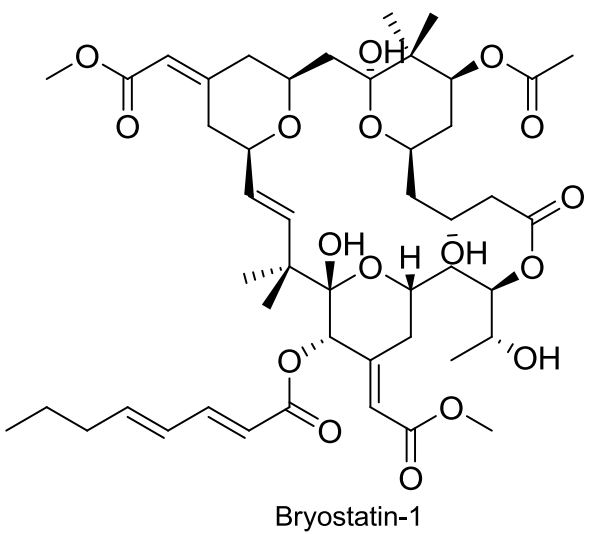

(Bryozoan Bugula neritina)

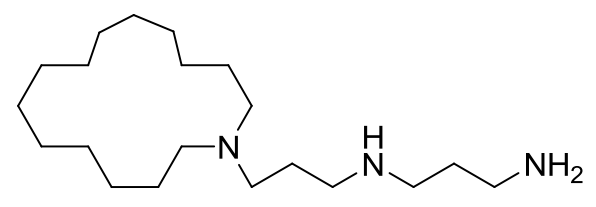

Dihydromotuporamine $\mathrm{C}$ (Sponge Xestospongia exigua)

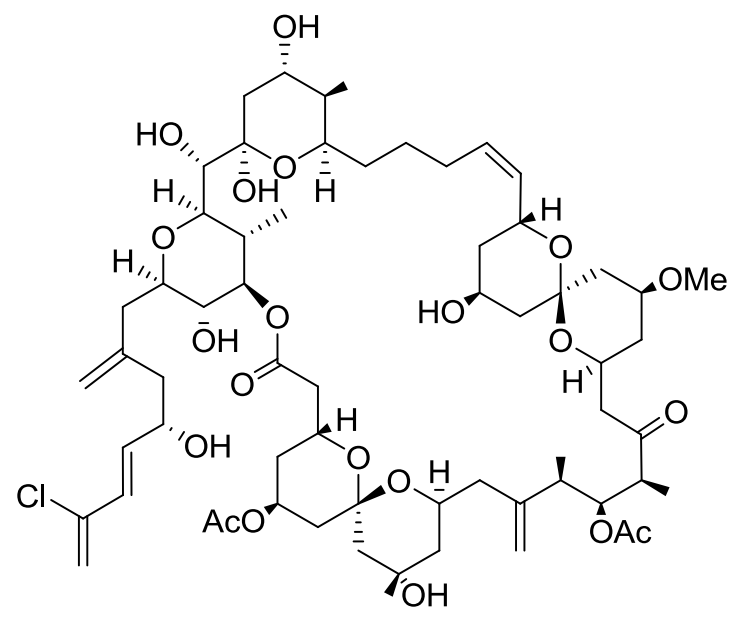

Spongistatin 1

(Sponge Hyrtios altum)

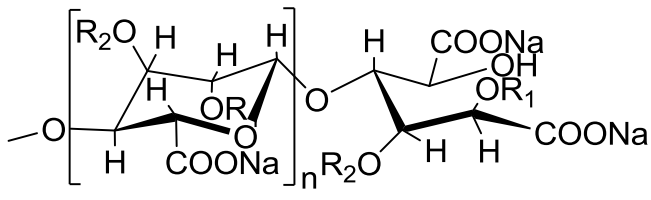

JG3

(Alga Sodium alginate)

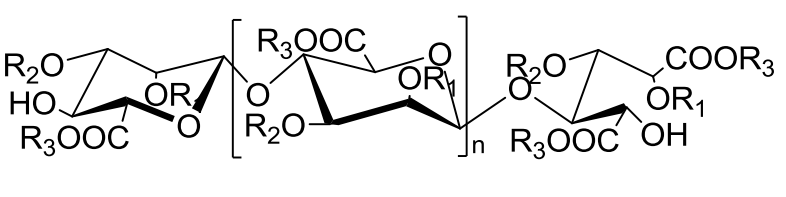

MdOS

(Alga sodium alginate) 
Figure 2. Structures and sources of terpenes, alkaloids and pyrones. SC2051, R = I; hypochromins $\mathrm{A}, \mathrm{R}=\overbrace{\xi}^{\mathrm{OH}}$; and hypochromins $\mathrm{B}, \mathrm{R}=\mathrm{CH} 3$.

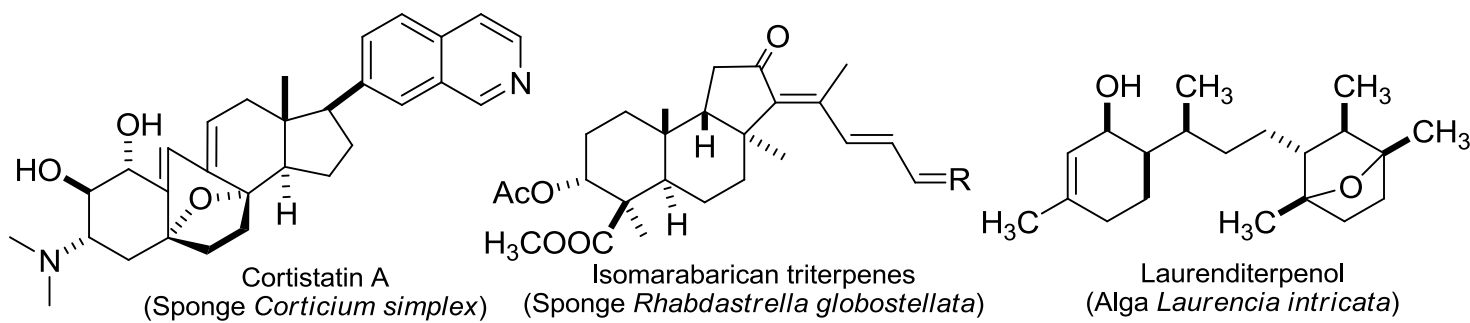

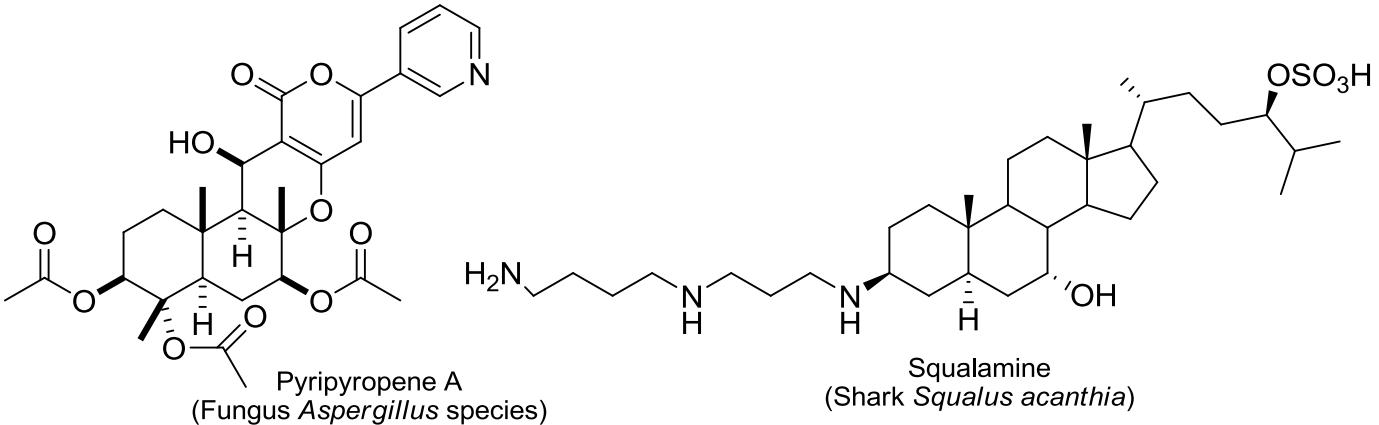
(Fungus Aspergillus species)

(Shark Squalus acanthia)<smiles>Nc1nc2c(-c3cc(Br)c(Br)[nH]3)nccc2[nH]1</smiles>

Ageladine A (Sponge Agelas nakamurai)<smiles>CC(C)(C)c1[nH]cnc1/C=c1\[nH]c(=O)/c(=C/c2ccccc2)[nH]c1=O</smiles>
(a synthetic analogue of phenylahistin from fungus Aspergillus species)<smiles>O=C1c2ccccc2-[n+]2ccc3c([nH]c4ccccc43)c21</smiles>

Fascaplysin (Sponge Fascaplysinopsis species)

\section{Streptochlorin} (Actinomycete Streptomyces species)<smiles>CCCCOCCOCCOCCO</smiles>

(Sponge Aplysinellidae)<smiles></smiles>

SC2051, hypochromins A and B (Fungus Hypocrea vinosa) 
Figure 3. Structures and sources of peptides, saponins and xanthones. norlichexanthone, $\mathrm{R}=\mathrm{H}$; anomalin $\mathrm{A}, \mathrm{R}=\mathrm{OH}$.

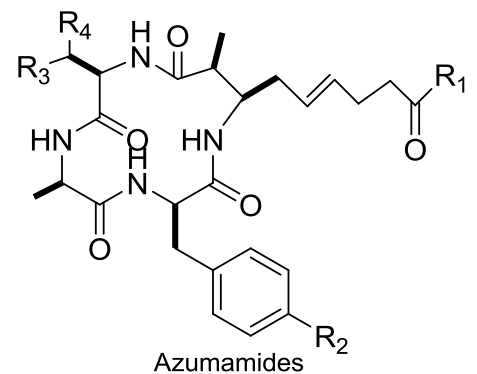<smiles>C=CC/C=C/N(C)C(=O)CCCCCCCC/C=C/C(N)=C/CSC[C@@H](N)/C=C/CCCCCCCCCC(=O)N(C)/C=C/CC=C</smiles>

(Sponge Mycale izuensis)

(Algae Lyngbya majuscula/ Schizothrix species)

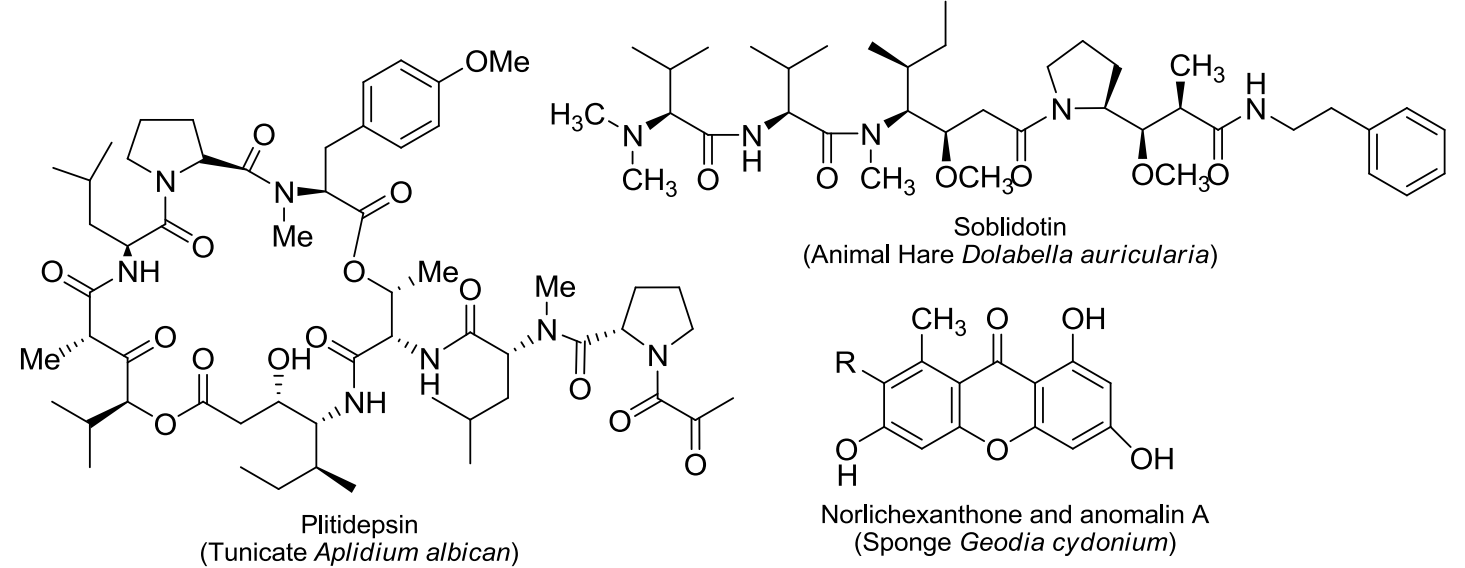

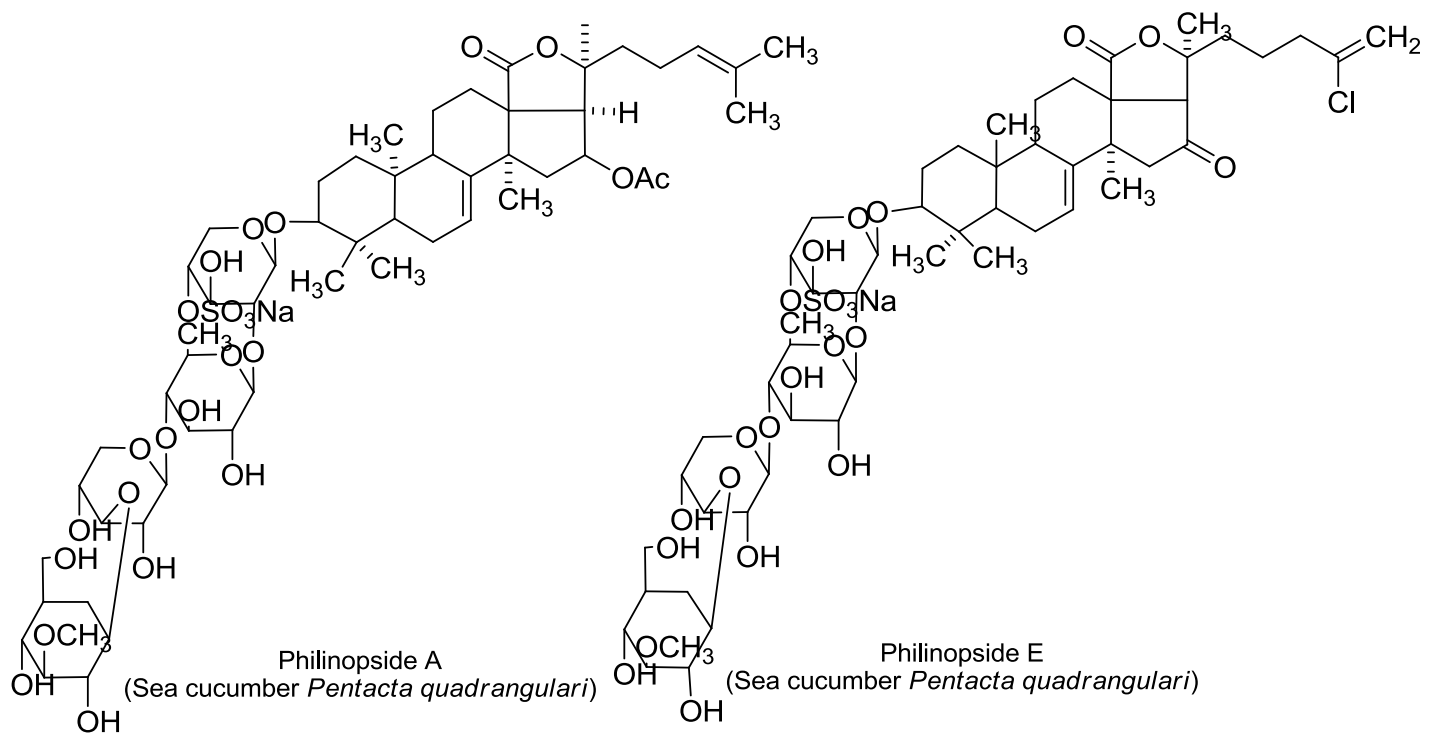


Figure 4. Structures and sources of other compounds.
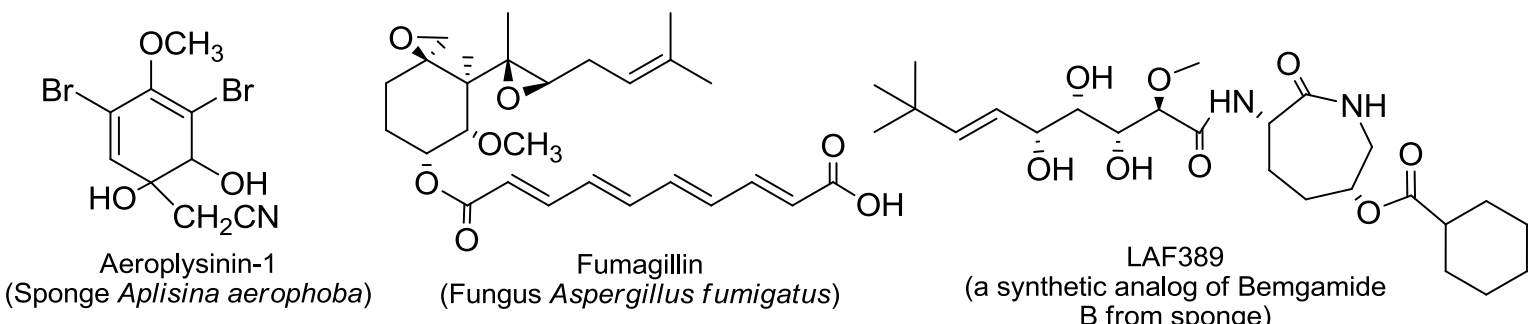

$B$ from sponge)

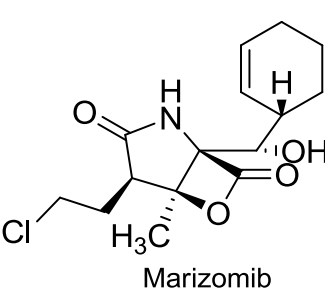

(Bacterium Salinispora tropica)

$\mathrm{OH}$<smiles>O=C(C(O)c1ccccc1)n1cc(-c2ccc(O)cc2)c(-c2ccc(O)cc2)c1</smiles><smiles>O=C(NCCSSCCNC(=O)/C(Cc1ccc(O)c(Br)c1)=N/O)/C(Cc1ccc(O)c(Br)c1)=N/O</smiles>

(Sponge Poecillastra/ Jaspis species)<smiles>CC1CC(=O)NC1Cc1ccccc1</smiles>

Streptopyrrolidine (Actinomycete Streptomyces species)<smiles></smiles>

TNP-470

(a synthetic analogue of Fumagillin)

\subsection{Protein Kinase Modulators}

According to the difference in phosphorylating amino acids, protein kinases can be primarily classified into two types: tyrosine kinases (TKs) and serine/threonine kinases (S/TKs). TKs contain two large families: transmembrane receptor-linked kinases (RTKs) and cytoplasmic (non-receptor) tyrosine kinases (CTKs). VEGFR, platelet-derived growth factor receptors (PDGFR), fibroblast growth factor receptor (FGFR) and EGFR belong to RTKs while focal adhesion kinase (FAK), janus kinase (JAK) and sarcoma kinase (Src) are CTKs. Most of these kinases are frequently aberrantly activated in cancer and involved in tumor angiogenesis. The most famous $\mathrm{S} / \mathrm{TKs}$ include protein kinase $\mathrm{C}$ (PKC) and cyclin-dependent kinases (CDKs). Of the 43 marine-derived antiangiogenic agents included in this present review, 14 are able to modulate protein kinases, which can be further divided into TK inhibitors (11) and S/TK modulators (3). These agents will be discussed separately in the second section.

\subsection{Cytoskeleton Disturbing Agents}

Microtubule and actin are the major structural compositions of cytoskeleton that is involved in many important cellular events including cellular shape, mitosis, movement, signaling transduction and substance transportation. Agents targeting microtubule such as taxol and vincristine are also clinically important anticancer drugs, and some of them show apparent antiangiogenic and/or antivascular properties [10]. Six marine-derived cytoskeleton disturbing agents (plinabulin, soblidotin, spongistatin 1, laulimalide, cytochalasin $\mathrm{E}$ and dihydromotuporamine $\mathrm{C}$ ) have been shown to inhibit angiogenesis 
and/or to disrupt the established tumor vasculature. Among them, plinabulin (Figure 2) and soblidotin (Figure 3) entered phase II clinical trials.

Among the four microtubule inhibitors, three (plinabulin, soblidotin and spongistatin 1) inhibit tubulin polymerization while one (laulimalide) promotes it. These inhibitors have distinct binding sites on microtubule. Soblidotin (TZT-1027), a synthetic derivative of dolastatin-10 isolated from the Indian Ocean sea hare Dolabella auricularia, has two microtubule-binding sites of low and high affinity, partially overlapping the vinblastine-binding site of tubulin [11]. Plinabulin (NPI-2358), a synthetic analogue of phenylahistin (NPI-2350) isolated from marine fungus Aspergillus sp., interacts with the interfacial region of $\alpha$ - and $\beta$-tubulin, which partially overlaps with the colchicine binding site [12]. The binding site of spongistatin 1 (Figure 1) is unknown but different from that of vinblastine [13]. In contrast, the tubulin polymerization agent laulimalide (Figure 1) binds to the exterior of the microtubule on $\beta$-tubulin, a binding site different from the taxol-binding site $[14,15]$. Despite these differences, all the 4 inhibitors possess potent cytotoxicity in various tumor cells in vitro and in vivo. They also cause cell cycle arrest in the $\mathrm{G}_{2} / \mathrm{M}$ phase and induce apoptosis [16-19]. And also due to the differences in their binding to tubulin or their unique structural characteristics, some of them such as plinabulin and laulimalide are highly effective even in cancer cells with resistance to taxol or multidrug resistance (MDR) [14,20].

These four microtubule inhibitors show potent angiogenesis inhibitory activity in a variety of angiogenesis experimental models (Table 1). Some inhibitors could prominently inhibit angiogenesis at much lower concentrations/doses than cytotoxic ones [21,22], suggesting the involvement of additional mechanism(s) apart from their microtubule inhibition. Actually, spongistatin 1 could inhibit the enzymatic activity and intracellular translocation of PKC $\alpha$ that is an essential kinase in angiogenesis [21]. Laulimalide could block integrin-associated signaling pathways through suppressing the phosphorylation of FAK and paxillin and the association of VEGFR-2 with FAK and heat shock protein 90 (Hsp90), although it did not inhibit the phosphorylation of VEGFR-2 [22]. In addition to its antiangiogenic activity, soblidotin shows its antivascular effect at a little higher concentrations, which might be independent of its microtubule inhibition [23,24]. Of note, plinabulin demonstrates significant vascular disrupting activity by acting on established tumor blood vessels. This activity has been considered to result from its inhibiting tubulin polymerization, which impairs cytoskeletal function and leads to selective tumor vascular endothelial architectural destabilization and vascular collapse [25].

Table 1. Assays used to test for angiogenesis inhibitory activity of agents reviewed in this paper. One or more models were used in the cited studies for the discussed agents.

\begin{tabular}{|l|}
\hline In vitro assays: \\
\hline - \\
Proliferation, migration, adhesion, monolayer permeability, or tube formation of \\
endothelial cells [human umbilical vein endothelial cells (HUVECs), human \\
microvascular endothelial cells (HMECs), human umbilical artery endothelial cells \\
(HUAECs), or bovine aortic endothelial cells (BAE)]
\end{tabular}


Table 1. Cont.

\begin{tabular}{|l|}
\hline \multicolumn{1}{c|}{ In vivo assays: } \\
\hline - Chicken chorioallantoic membrane (CAM) assays \\
- Choroidal neovascularization membranes (CNVMs) assays in rats \\
- Corneal angiogenesis assays in mice or rabbits \\
- Matrigel plug assays in mice \\
- Tumor vessel density assays by immunohistochemistry in xenografts \\
\hline
\end{tabular}

Both cytochalasin E (Figure 1) and dihydromotuporamine C (Figure 1) target actin. However, cytochalasin $\mathrm{E}$ leads to actin depolymerization only at relatively high concentrations. Cytochalasin $\mathrm{E}$ at lower concentrations preferentially inhibits endothelial cell proliferation without disrupting actin stress fibers [26]. It also suppresses the phosphorylation of FAK, which may be critical to its antitumor activity [27]. Interestingly, cytochalasin $\mathrm{E}$ was reported to activate $\mathrm{PKC}$, leading to the induction of interleukin-8 production and the up-regulation of CD54 [28,29]. Dihydromotuporamine C is one of nine members in the motuporamines family (motuporamine A-I). It could increase the thickness and number of cytoplasmic actin stress fibers, induce the formation of new stress fibers and large focal adhesion complexes, activates the small GTP-binding protein Rho, and stimulate the Rho-dependent sodium-proton exchanger activity. Its ability to activate Rho has been considered to be one important determinant of its anti-invasive activity [30]. As other members in this family, dihydromotuporamine $\mathrm{C}$ shows very low cytotoxicity or cell proliferation inhibition. Both cytochalasin $\mathrm{E}$ and dihydromotuporamine $\mathrm{C}$ displayed antiangiogenesis activity in different in vitro and in vivo models (Table 1) [26,31].

\subsection{HDAC Inhibitors}

HDACs are the enzymes that remove acetyl groups from target proteins that regulate their activity. Eighteen human HDACs have been found that can be divided into four classes (class I-IV). HDACs are important anticancer targets, and 2 HDAC inhibitors were approved by FDA (vorinostat in 2006 and romidepsin in 2009) for treating cutaneous T-cell lymphoma [32]. Three marine-derived HDAC inhibitors including panobinostat (Figure 4), azumamides A-E (Figure 3) and psammaplin A (Figure 4) have been reported to inhibit angiogenesis. Panobinostat (LBH589), one of the most potent HDAC inhibitors, can inhibit all known HDACs, which leads to $G_{2} / M$ cell cycle arrest and proliferation inhibition [33]. At noncytotoxic concentrations, panobinostat also inhibits the phosphorylation of protein kinase B (AKT) and extracellular signal-regulated kinase (ERK) 1/2, and the expression of the chemokine receptor CXCR4. Panobinostat exerts antiangiogenesis activity evidenced by its inhibition of endothelial tube formation and Matrigel invasion, and its reduction of angiogenesis in PC-3 xenografts in mice [34]. Azumamides A-E are HDAC inhibitory cyclic tetrapeptides isolated from the marine sponge Mycale izuensis. Azumamide A displayed significant inhibition of vascular formation [35]. The data from an in vitro vascular organization model using mouse induced pluripotent stem (iPS) cells revealed that the antiangiogenic activity of azumamides was closely correlated with their HDAC inhibition [36]. Psammaplin A from marine sponges potently inhibits HDAC enzyme (an $\mathrm{IC}_{50}$ value of $4.2 \mathrm{nM}$ ) [37] and relatively weakly suppresses mammalian aminopeptidase $\mathrm{N}$ (an $\mathrm{IC}_{50}$ value of $18 \mu \mathrm{M})$ [38]. Psammaplin A causes upregulation of the CDK inhibitor $\mathrm{p} 21^{\mathrm{WAF} 1}$ and downregulation of 
pRb, cyclins and CDKs [39]. Psammaplin A has potent antiproliferative activity against various tumor cells and significant antiangiogenesis effects in different vascular formation models (Table 1) [38,40].

\subsection{MetAPS Inhibitor}

MetAPs are the essential metalloproteins that remove the initiator $\mathrm{NH}_{2}$-terminal methionine from nascent proteins. Two types of MetAP enzymes, MetAP-1 and MetAP-2, have been reported. MetAP-2 has been investigated as anticancer and antiangiogenesis targets since the discovery that the marine natural product fumagillin (Figure 4) irreversibly inhibits MetAP-2 (rather than MetAP-1), impairs angiogenesis, and elicits anticancer activity [41-43]. Fumagillin covalently binds to His231 of MetAP-2 that is located in the active site of the enzyme and thus prevents the binding of substrates to MetAP-2 [43]. Nevertheless, how MetAP-2 regulates angiogenesis and how fumagillin inhibits it remain to be clarified. TNP-470 (Figure 4) is a semisynthetic analogue of fumagillin with 50-fold increase in inhibiting neovascularization and angiogenesis. TNP-470 potently and selectively acts on endothelial cells. It inhibits endothelial proliferation in vitro at a concentration 3 logs lower than that required to inhibit the proliferation of fibroblasts and tumor cells [44]. TNP-470 was also reported to inhibit FGF1-stimulated angiogenesis both in vitro and in vivo through the binding to the cytoplasmic domain of the FGF1 receptor [45].

Different from fumagillin, the marine natural products bengamides inhibit both MetAP-1 and MetAP-2 with similar potency. Different bengamides can bind to the active center of the enzymes but in differential binding modes [46]. LAF389 (Figure 4) is a synthetic analogue of bengamide B. LAF389 significantly inhibits tumor growth and proliferation, apparently by means of MetAP inhibition [47,48]. LAF389 demonstrates a marked inhibition of tumor vascularization in animal experiments. However, no antiangiogenic activity data was obtained from patients owing to the early discontinuation of its phase I clinical trials [49].

\subsection{Others}

There are additional marine natural products that show antiangiogenic activity in different models (the tube formation assay was used most widely) (Table 1) but via unique or unknown mechanisms. Some of them were reported only in few studies. For example, puupehenone (Figure 2) was revealed to inhibit the tube formation of endothelial cells and the in vivo angiogenesis in the CAM assay [50]; streptochlorin (Figure 2) suppresses the invasion and VEGF-stimulated tube formation of endothelial cells [51]; the lipopeptide somocystinamide A (Figure 3) impairs the proliferation and tube formation of endothelial cells and inhibits the angiogenesis in zebrafish or CAM models [52]; bastadin 6 (Figure 1), pyripyropenes A (Figure 2) and isomarabarican (Figure 2) highly selectively inhibit the proliferation, migration and tube formation of endothelial cells, and bastadin 6 also blocks the VEGF- or bFGF-induced in vivo angiogenesis of mice corneas [53-55]; and streptopyrrolidine (Figure 4) significantly blocks the tube formation of endothelial cells at a non-cytotoxic concentration [56]. Several saccharides mainly from marine algae such as SargA from Sargassum stenophyllum [57], sulfated galactan from Codium cylindricum [58] and a series of fucoidans from different brown algae species, also show antiangiogenic activity to different degrees $[59,60]$. In addition, there are still some other marine-derived agents that can interfere with angiogenesis-related signaling although no direct 
antiangiogenesis activity has been reported yet. Two examples are laurenditerpenol (Figure 2) and neolamellarin A (Figure 4), both of which can inhibit the activation of hypoxia-inducible factor (HIF)-1, a critical event in tumor neoangiogenesis $[61,62]$.

In contrast, another three antiangiogenesis agents have been investigated in more detail and all of them entered clinical trials. The marine-derived depsipeptide plitidepsin (dehydrodidemnin B, aplidine) (Figure 3), the aminosterol squalamine (Figure 2) and the proteasome inhibitor marizomib (NPI-0052, salinosporamide A) (Figure 4) all show the antiangiogenic effect in multiple in vitro and in vivo angiogenesis models (Table 1). Plitidepsin could block the secretion of VEGF by tumor cells and the production of MMP by endothelial cells [63], and reduce the expression of anigiogenesis-related genes including VEGF and HIF-1 [64]. Its antiangiogenic activity contributed to its antitumor effects [65]. However, the primary target(s) of plitidepsin remain to be discovered. Squalamine alters intracellular $\mathrm{pH}$ and impedes the growth factor signaling, possibly by selectively inhibiting the sodium-hydrogen antiporter exchanger of the endothelial cell surface. It exerts the greatest effect on newly emerging vessels with no appreciable effect on unstimulated endothelial cells [66-68]. Additionally, squalamine shows potential antitubercular and antimicrobial activities [69,70]. Marizomib inhibits 20S proteasome by covalently modifying its active site threonine residues and exhibits therapeutic activity against a wide variety of tumors [71]. Marizomib significantly interferes with several angiogenesis-associated factors, including VEGF-dependent migration [72], TNF- $\alpha$-induced VEGF expression [73], and downregulation of HIF-1 $\alpha$ and HIF-2 $\alpha$ proteins and VEGF secretion [74], inhibition of both constitutive and inducible prosurvival transcription factor NF- $\mathrm{KB}[73,74]$.

\section{Marine-Derived Protein Kinase Modulators with Antiangiogenic Activity}

Two types of the marine-derived protein kinase modulators, i.e., S/TK modulators and TK inhibitors have been reported to have antiangiogenic activity

\subsection{S/TK Modulators}

$\mathrm{S} / \mathrm{TK}$ s are a large protein kinase family, including PKC, CDKs and Rho-associated, coiled-coil containing protein kinase (ROCK). Several S/TK-targeted marine-derived natural products showed antiangiogenic activity in different models (Table 1). Of them, bryostatin-1 has entered phase II clinical trials.

\subsubsection{The PKC Activator Bryostatin-1}

The PKC family contains at least 12 isozymes characteristic of different structures, functions, subcellular localization, and substrate specificity. Most PKC activators such as the phorbol ester 12-O-tetradecanoylphorbol-13-acetate (TPA) are potent tumor promoters. In contrast, the PKC activator bryostatin-1 (Figure 1), a monocyclic lactone originally derived from a marine bryozoan and now available by synthesis, shows unique anticancer activities with little tumor promotion [75]. Similar to TPA, bryostatin-1 can activate almost all PKC isozymes [76], indicating that its anticancer effects cannot be elicited only through its PKC activation. Actually, there is an important difference between bryostatin-1 and TPA that is their distinct impacts on the proposed tumor suppressor PKC $\delta$. TPA 
downregulates it whereas bryostatin-1 does not, even at high concentrations [77,78]. Such a difference might result from their distinct binding modes: TPA selectively binds to the $\mathrm{C} 1 \mathrm{~B}$ domain but bryostatin-1 binds to both $\mathrm{C} 1 \mathrm{~A}$ and $\mathrm{C} 1 \mathrm{~B}$ domains of PKC $\delta$ [75]. Nevertheless, the exact molecular mechanisms that mediate bryostatin-1's unique anticancer activities still need further investigating. Bryostatin-1 can potentially inhibit tumor invasion, angiogenesis, cell adhesion, and limit the development of MDR by regulating PKC activity [79,80].

\subsubsection{The CDK4 Inhibitor Fascaplysin}

The marine natural product fascaplysin (Figure 2) inhibits CDK4 with more than 1400-fold selectivity over its close homolog CDK2. The positive charge in its structure is crucial for this high selectivity [81]. Fascaplysin can block VEGF, inhibit proliferation and induce apoptosis of human umbilical vein endothelial cells (HUVECs) [82]. These activities could contribute to its antiangiogenic effects shown in multiple in vitro and in vivo experimental models (Table 1) [83,84].

\subsubsection{Cortistatin A}

Cortistatins (Figure 2) are a family of eleven steroidal alkaloids isolated from the marine sponge Corticium simplex. Of them, cortistatin A shows the most potent antiangiogenic activity. It could selectively inhibit the proliferation, migration and tube formation of HUVECs [85], which might be associated with its suppression of the phosphorylation of the unidentified $110 \mathrm{kDa}$ protein in HUVECs [86] and some kinases such as ROCK, CDK8 and CDK11 [87]. The dimethylamino group and isoquinoline unit in the side chain of cortistatin A could be crucial for its antiangiogenic and kinase inhibitory activities [86].

\subsection{TK Inhibitors}

Numerous TKs such as VEGFR, EGFR, PDGFR and FGFR play critical roles in tumor angiogenesis, which are the major target (s) of most small-molecule angiogenesis inhibitors in the clinic including sorafenib and sunitinib [7]. As yet, however, only 11 TK-targeted marine-derived angiogenesis inhibitors have been reported, not so many as expected. Among them, neovastat (AE-941) entered phase III clinical trials but failed unfortunately, and the others are still in very early investigation stages.

\subsubsection{Neovastat}

The antiangiogenic activity of neovastat, an extract from shark cartilage, has been widely investigated. Neovastat inhibits CAM vascularization and Matrigel-induced angiogenesis [88]; it competitively suppresses the VEGF-dependent phosphorylation of VEGFR, the proliferation of endothelial cells, and VEGF-induced vascular permeability in mice [89]. Neovastat could also inhibit MMP-2 [90] but stimulate tissue plasminogen activator (tPA) [91] and activate caspase-mediated apoptotic pathways in endothelial cells [92]. In addition, neovastat has significant antitumor and antimetastatic activity [93]. Although its phase II clinical trials were reported to produce positive therapeutic effects, subsequent 2 phase III clinical trials of neovastat failed in either stage III non-small cell lung cancer or metastatic renal cell carcinoma [94-96]. Moreover, "Sharks don't get cancer" has 
been found to be not the case [97]. Therefore, the development of neovastat as an anticancer drug is likely to be ended.

\subsubsection{Aeroplysinin-1}

Aeroplysinin-1 (Figure 4) is a marine-derived brominated tyrosine metabolite that has antibacterial, antiparasitic, anticancer and antiangiogenic activities. Using different in vitro and in vivo models (Table 1), aeroplysinin-1 has been demonstrated to inhibit the key steps of angiogenesis [98]. Its antiangiogenic activity would be associated with its selective apoptotic induction in endothelial cells via the intrinsic apoptosis pathway [98]. This selectivity may result from its significant inhibition of EGFR [99] and VEGFR-2 [100]. Additionally, new synthetic derivatives of aeroplysinin-1 demonstrate promising antiangiogenic potentials [100].

\subsubsection{Philinopside A and Philinopside E}

Both are sulfated saponins isolated from the sea cucumber Pentacta quadrangulari. Philinopside A and E (Figure 3) displayed their antiangiogenic activity including inhibition of the proliferation, migration and tube formation of endothelial cells and the vascularization in the rat aorta ring culture assay, the CAM assay or mouse tumor models. The angiogenesis inhibition could result from their suppression of angiogenesis-related RTKs including VEGFR, FGFR-1, PDGFR, EGFR and their related signaling transduction $[7,101,102]$.

\subsubsection{Ageladine A}

The brominated pyrrole-imidazole alkaloid Ageladine A (Figure 2) was first isolated from the marine sponge Agelas nakamurai but now can be obtained by synthesis using different methods [103-107]. Ageladine A exhibited in vitro and in vivo antiangiogenic activity (Table 1), which was initially considered to be associated with its MMP inhibition [108] but subsequently confirmed to result from its selective inhibition of kinases including dual specificity tyrosine-phosphorylation-regulated kinase (DYRK) 1A, DYRK2, tyrosine kinase 2 (TYK2) and yeast Sps1/Ste20-related kinase 4 (YSK4) [103]. One of the most impressive features of ageladine A and some of its synthetic analogues is their highly selective angiogenesis inhibition because no cytotoxicity was found in the National Cancer Institute (NCI) panel of 60 human cancer cell lines at their antiangiogenic concentrations. In addition, ageladine A is also a pH-sensitive fluorescent dye that may be used for imaging [109,110].

\subsubsection{Saccharides}

Several marine-derived saccharides, mainly from sea algae, have been reported to inhibit tumor angiogenesis, which is related to their TK inhibition. The semi-synthesized oligomannurarate sulfate JG3 (Figure 1) shows significantly antiangiogenic and antimetastatic activities. On one hand, JG3 impairs the activity of heparanase via binding to its KKDC (KKFKNSTYSRSSVDC amino acids) and QPLK (QPRRKTAKMLK amino acids) domains; on the other, JG3 reduces the bFGF-induced phosphorylation of bFGFR and ERK1/2 [111]. In contrast, another semi-synthesized oligosaccharide MdOS (Figure 1) (Marine-derived Oligosaccharide Sulfate) exerts its antiangiogenic effect that is 
dependent on its broad-spectrum TK inhibition on human epidermal growth factor receptor-2 (HER2), EGFR, VEGFR, PDGFR, c-Kit, FGFR1 and c-Src. MdOS acts as an ATP-competitive inhibitor of these TK enzymes [112].

Sulfated polysaccharides such as fucoidans and SargA were shown to modulate angiogenesis. Different fucoidans showed totally different effects on angiogenesis, which varied according to their molecular weight and sulfated degree. Low molecular weight fucoidans (4-9 kDa) were found to stimulate angiogenesis in different assays [113-115]; middle molecular weight fucoidans (15-20 kDa) could enhance HUVEC migration but did not inhibit HUVEC tube formation; and natural fucoidan had high molecular weight $(30 \mathrm{kDa})$ and antiangiogenic properties shown by inhibition of the proliferation, migration and tube formation of endothelial cells and vascular network formation [59,116,117]. On the other hand, oversulfated fucoidan inhibited angiogenesis (the bFGF-induced migration and tube formation of HUVECs) apparently more potently than natural or desulfated fucoidan [118,119]. SargA, a sulfated heteropolysaccharide extracted from the brown marine alga Sargassum stenophyllum, was also reported to exhibit antiangiogenic activity in vitro and in vivo (Table 1) [57,120]. The antiangiogenic mechanisms of these sulfated polysaccharides are likely associated with their interfering with the phosphorylation of bFGFR, ERK1/2 or FAK $[57,120,121]$.

\subsubsection{Anomalin A and Norlichexanthone}

The xanthones anomalin A and norlichexanthone (Figure 3) can be isolated from the sponge-derived fungus Arthrinium sp. Both were shown to inhibit the proliferation of cancer cells and the activity of multiple protein kinases such as anaplastic lymphoma kinase (ALK), AMPK-related protein kinase (ARK5), Aurora-B, insulin-like growth factor-1 receptor (IGF1-R), pim kinase-1 (PIM1), polo-like kinase 1 (PLK1), PKC-related kinase 1 (PRK1), Src and VEGFR-2, but anomalin A was more potent and had a different spectrum of action $[122,123]$. This may be one of the reasons why anomalin A could inhibit VEGF-A dependent endothelial cell sprouting whereas norlichexanthone could not [123].

\subsubsection{SC2051 and hypochromins A and B}

SC2051 and hypochromins A and B (Figure 2), all with bis (naphtho- $\gamma$-pyrone) skeletons, were isolated from the marine-derived fungi Hypocrea Vinosa. All three compounds showed tyrosine kinase inhibitory activity and could elicit antiangiogenic effects in assays for the proliferation, migration, and tube formation of endothelial cells [124].

\section{Clinical Trials of Marine-Derived Angiogenesis Inhibitors for Cancer Therapy}

Ten marine-derived angiogenesis inhibitors entered clinical trials for cancer therapy, but 5 of them failed in different stages. The phase III clinical trials of the shark cartilage extract neovastat [94-96] and the phase II clinical trials of the tubulin inhibitor soblidotin $[125,126]$ failed due to the lack of the expected therapeutic efficacy. The development of MetAPs inhibitors LAF389 and TNP-470 was also stopped in either phase I or phase II due to the severe toxicities or the lack of positive therapeutic effects $[49,127,128]$. In addition, although the aminosterol squalamine showed tolerable toxicity in phase I/IIA clinical trials [129], there have been no reports about its clinic development in recent ten 
years. Therefore, we here only discuss the clinical data of the other five marine-derived angiogenesis inhibitors, i.e., bryostatin-1, panobinostat, plitidepsin, marizomib and plinabulin.

\subsection{The PKC Activator Bryostatin-1}

Since 1993, over 80 separate phase I and II clinical trials for cancer therapy using bryostatin-1 alone or in combination with conventional anticancer drugs have been conducted [8]. Different types of human cancers have been investigated in these clinical studies, including chronic lymphocytic leukemia, non-Hodgkin lymphoma, multiple myeloma, melanoma, renal cell carcinoma, colorectal cancer, soft tissue sarcoma, head and neck cancer, ovarian cancer, cervix carcinoma, gastric cancer, gastroesophageal cancer, esophageal cancer and pancreatic carcinoma [79,130-150]. From the results of its clinical trials, several important conclusions can be drawn: (1) Myalgia is its main human dose-limiting toxicity with the occurrence of $10 \%-87.5 \%$ found in phase II trials [151]. Although the precise mechanism of bryostatin-1-triggered myalgia remains unknown, it could be manageable by some measures such as exercise, taking analgesics, and dose control. Nevertheless, myalgia is still an important reason for ending clinical studies [151]. (2) Bryostatin-1 alone failed to produce adequate therapeutic effects in almost all examined hematological malignancies and solid tumors. (3) However, its combination with various conventional anticancer drugs seems encouraging. In particular, the combination of bryostatin-1 with paclitaxel, cisplatin or vincristine in phase II clinical studies produced promising therapeutic effects [146-148,150]. (4) The important characteristics of bryostatin-1 in these combinations might include its circumvention of tumor MDR and no or limited overlapping toxicities with the conventional anticancer drugs. Therefore, bryostatin-1 is possible to prevent or delay the occurrence of tumor MDR to the combined drug (s) such as paclitaxel or vincristine [148]. On the other hand, the toxicities of the combinations would not increase compared with those of their separate uses [75]. (5) As a PKC activator, bryostatin-1 is possible to act as a tumor promoter to accelerate the growth of some tumors although it has little tumor-promoting activity [75,152]. To reduce this risk, it may need to develop appropriate molecular biomarkers for the selection of patients and the therapeutic surveillance in its clinical studies and potential uses.

In addition, although the antiangiogenic activity of bryostatin-1 was shown in preclinical studies, it was not reported in any clinical trials. So it could not be concluded whether the antiangiogenic activity practically contributes to the clinical anticancer effects of bryostatin-1. According to the present clinical results, the clinical development of bryostatin-1 is faced with several major challenges, including how to reduce its toxicity (mainly myalgia), increase its therapeutic efficacy (mainly through combination with other anticancer drugs), and develop proper molecular biomarkers for the selection of patients and the therapeutic surveillance. Another problem is its very limited yield from natural resources. Moreover, it is also hard to be synthesized [75]. However, because of its unique PKC modulation and anticancer activity, more potent analogues of bryostatin-1 deserve testing in the clinical arena.

\subsection{The HDAC Inhibitor Panobinostat}

The marine-derived angiogenesis inhibitor panobinostat is among the most potent HDAC inhibitors [153]. It is undergoing extensive phase I and phase II clinical trials with 114 clinical studies [154]. Panobinostat is orally or intravenously available [153]. The major toxicities of panobinostat in humans 
are hematologic (including thrombocytopenia, neutropenia, anemia and leukopenia), fatigue, and gastrointestinal (nausea and diarrhea) but generally manageable [155-162]. Although phase II clinical trials of panobinostat have been conducted in solid (e.g., renal and pancreatic) cancers, the reported positive responses to its single-agent therapy have been predominantly observed in advanced hematologic malignancies including T-cell lymphoma, Hodgkin lymphoma, Waldenström macroglobulinemia, and myelodysplastic syndrome [155-162], showing a similar clinical anticancer spectrum to other HDAC inhibitors. However, the response of multiple myeloma to panobinostat monotherapy was just modest $[156,157]$. The combination of panobinostat with other anticancer drugs could expand its potential clinical applications. Its combination with paclitaxel and carboplatin reported in a phase I study [163] was well tolerated. In contrast, the combination of panobinostat, bevacizumab and everolimus was not tolerable [164]. The results are interesting because all panobinostat, paclitaxel and carboplatin can inhibit bone marrow but both bevacizumab and everolimus have very limited hematologic adverse effects. The results suggest that the toxicity of these combinations may have additional determinants and careful selection of its combined drugs is very important. The results also suggest that in addition to histone hyperacetylation, other biomarkers more relevant to the clinical therapeutic efficacy and toxicity of panobinostat are urgently needed [165].

\subsection{The Cyclic Depsipeptide Plitidepsin}

Plitidepsin is undergoing phase I and phase II clinical studies and its pivotal randomized phase III trial is also ongoing in patients with relapsed/refractory multiple myeloma [166,167]. Phase I results show that plitidepsin has a unique toxicity profile that is similar in children and adult cancer patients [168]. Its main dose-limiting toxicities are muscular and hepatic toxicities. The most common muscular toxicities are myalgia and asthenia with unknown mechanisms, and co-treatments with L-carnitine can prevent them or accelerate their recovery [168-170]. Its hepatic toxicities are transaminase increases but generally reversible. Other toxicities of plitidepsin include fatigue, pyrexia, skin rash, abdominal pain, nausea, vomiting and diarrhea. Of note, plitidepsin does not significantly inhibit bone marrow at pharmacological concentrations $[168,170]$. Moreover, it does not seem to produce cross-resistance between plitidepsin and other conventional anticancer drugs [171]. These two characteristics are important for they provide a critical basis for its clinical combination designs with the drugs that are myelosuppressive and/or sensitive to drug resistance mechanisms.

Phase II studies with plitidepsin monotherapy further confirmed its favorable safety profile, but did not demonstrate significant clinical anticancer activity in solid tumors such as unresectable advanced medullary thyroid carcinoma [172], refractory advanced malignant melanoma [173], pretreated small cell lung cancer [174] and pretreated non-small cell lung cancer [175]. In contrast, the recently released results of a phase II study with single-agent plitidepsin revealed its clinical activity with an overall response rate of $20.7 \%$ (6 of 29; 2 complete responses and 4 partial responses) in patients with non-cutaneous peripheral T-cell lymphoma [176]. However, no responses were observed to other non-Hodgkin's lymphoma including B-cell lymphoma in the same study. Plitidepsin showed synergistic activity with rituximab in preclinical models of diffuse large cell and Burkitt lymphoma [166]. Its combination with dexamethasone in a phase II clinical trial also displayed therapeutic efficacy though limited [177]. Therefore, future clinical development of plitidepsin might predominantly test for its 
therapeutic efficacy against hematological malignancies, preferentially through combination with other anticancer drugs.

\subsection{The Proteasome Inhibitor Marizomib}

Preclinical data indicate that marizomib inhibits all three enzymatic activities of the proteasome with preferential inhibition of the chymotrypsin-like and trypsin-like proteasome enzymes. Therefore, marizomib could overcome the resistance to bortezomib that selectively inhibits the chymotrypsin-like activity of the proteasome. In addition, this broader spectrum of enzymatic activity inhibition is also likely to confer a differential anticancer spectrum and a different toxicity profile to marizomib. This unique feature provided the basis for the clinical development of marizomib although bortezomib has been approved for clinical uses [178]. Marizomib is undergoing phase I clinical trials. The results available indicate its safety and preliminary anticancer activity. The most common adverse events of marizomib observed in these clinical studies were fatigue, nausea, diarrhea, vomiting, and dysgeusia/anorexia. Its dose-limiting toxicity could be transient hallucinations (visual imprints when eyes closed) and dizziness/unsteady gait. Notably, marizomib did not cause myelosuppression (neutropenia and thrombocytopenia) or peripheral neuropathy that could be related to bortezomib. In addition, the combination with the HDAC inhibitor vorinostat did not enhance the toxicity of marizomib but could synergistically increase its therapeutic efficacy in patients with melanoma, pancreatic and lung cancer [179-181]. With marizomib monotherapy, stable disease was observed in patients with multiple myeloma, melanoma, cervical, colorectal, hepatocellular, adenoid cystic, granulosis cell or ovarian carcinoma [180,182]. Nevertheless, marizomib has a very short half-life of 4-10 min with clearance at $3-15 \mathrm{~L} / \mathrm{min}$ in patients, indicating that it is necessary to carefully adjust the administration schedule of marizomib so as to provide enough drug exposure to achieve clinical benefit $[180,183]$. Taken together, marizomib is well tolerated with a unique toxicity profile and has demonstrated preliminary therapeutic effects, which warrants its further clinical development.

\subsection{The Tubulin Inhibitor Plinabulin}

The tubulin inhibitor plinabulin is a vascular disrupting agent, two phase I trials of which have been reported. The first one was conducted using single-agent plinabulin in 38 patients with advanced solid tumors (including colorectal, pancreatic, breast, renal thyroid, adrenocortical or prostate carcinoma) or lymphomas (diffuse large cell non-Hodgkin's lymphoma) [184]. In contrast, the second one tested the combination of plinabulin with docetaxel in 13 patients with advanced non-small cell lung cancer, gastrointestinal stromal tumor, liposarcoma or melanoma [25]. The results showed its favorable safety profile with fatigue, tumor pain, nausea, diarrhea and vomiting as the most common but manageable adverse events. Fever, tumor pain, and transient hypertension were also observed. One dose limiting toxicity of nausea, vomiting, dehydration and neutropenia occurred. Drug-related neurologic toxicity or myelosuppression was not significant. Importantly, the combination of plinabulin and docetaxel did not increase their respective toxicities $[25,184]$. These phase I trials also demonstrated its antitumor activity. Plinabulin monotherapy achieved stable disease with a rate of $30 \%$ after 2 cycles [184]. Its combination with docetaxel led to a partial response in two patients and decreased tumors in four patients among total 
eight evaluable patients with non-small cell lung cancer [25]. These results support its further clinical development of either monotherapy or combination.

\section{Conclusions}

With the successful clinical uses of angiogenesis inhibitors and marine-derived anticancer drugs for cancer therapy, the development of marine-derived antiangiogenic agents is attracting more and more attention. To date, dozens of marine natural products and their synthetic analogues have been shown to inhibit angiogenesis or to disrupt established blood vessels, and several of them are undergoing anticancer clinical trials with encouraging results. Moreover, with the increasing exploration of marine sources, new marine angiogenesis inhibitors will continue to be found and developed, which will possibly offer more choices to the clinic for cancer therapy in future. In particular, marine-derived antiangiogenic protein kinase modulators will be hoped to achieve greater development, based on the critical roles of either TKs or S/TKs in tumor angiogenesis and the tremendous marine resources yet to be developed.

\section{Acknowledgements}

This work was supported by grants from the National Natural Science Foundation of China (NSFC) (No. 81025020, No. 81021062 and No. 81202548), the National Basic Research Program of China (No. 2012CB932502), the National Science \& Technology Major Project of China (No. 2012ZX09301-001-002), and the "Interdisciplinary Cooperation Team" Program for Science and Technology Innovation of the Chinese Academy of Sciences.

\section{Conflict of Interest}

The authors declare no conflicts of interest related to this work.

\section{References}

1. Hanahan, D.; Weinberg, R.A. Hallmarks of cancer: The next generation. Cell 2011, 144, 646-674.

2. Rapisarda, A.; Melillo, G. Role of the VEGF/VEGFR axis in cancer biology and therapy. Adv. Cancer Res. 2012, 114, 237-267.

3. Siefert, S.A.; Sarkar, R. Matrix metalloproteinases in vascular physiology and disease. Vascular 2012, 20, 210-216.

4. Yin, S.Q.; Wang, J.J.; Zhang, C.M.; Liu, Z.P. The development of MetAP-2 inhibitors in cancer treatment. Curr. Med. Chem. 2012, 19, 1021-1035.

5. Bayless, K.J.; Johnson, G.A. Role of the cytoskeleton in formation and maintenance of angiogenic sprouts. J. Vasc. Res. 2011, 48, 369-385.

6. Mottet, D.; Castronovo, V. Histone deacetylases: Anti-angiogenic targets in cancer therapy. Curr. Cancer Drug Targets 2010, 10, 898-913.

7. Miao, Z.H.; Feng, J.M.; Ding, J. Newly discovered angiogenesis inhibitors and their mechanisms of action. Acta Pharmacol. Sin. 2012, 33, 1103-1111. 
8. Mayer, A.M.S.; Glaser, K.B.; Cuevas, C.; Jacobs, R.S.; Kem, W.; Little, R.D.; McIntosh, J.M.; Newman, D.J.; Potts, B.C.; Shuster, D.E. The odyssey of marine pharmaceuticals: A current pipeline perspective. Trends Pharmacol. Sci. 2010, 31, 255-265.

9. Abraham, I.; El Sayed, K.; Chen, Z.S.; Guo, H. Current status on marine products with reversal effect on cancer multidrug resistance. Mar. Drugs 2012, 10, 2312-2321.

10. Schwartz, E.L. Antivascular actions of microtubule-binding drugs. Clin. Cancer Res. 2009, 15, 2594-2601.

11. Natsume, T.; Watanabe, J.; Tamaoki, S.; Fujio, N.; Miyasaka, K.; Kobayashi, M. Characterization of the interaction of TZT-1027, a potent antitumor agent, with tubulin. Jpn. J. Cancer Res. 2000, 91, 737-747.

12. Yamazaki, Y.; Sumikura, M.; Hidaka, K.; Yasui, H.; Kiso, Y.; Yakushiji, F.; Hayashi, Y. Anti-microtubule "plinabulin" chemical probe KPU-244-B3 labeled both $\alpha$ - and $\beta$-tubulin. Bioorg. Med. Chem. 2010, 18, 3169-3174.

13. Bai, R.; Taylor, G.F.; Cichacz, Z.A.; Herald, C.L.; Kepler, J.A.; Pettit, G.R.; Hamel, E. The spongistatins, potently cytotoxic inhibitors of tubulin polymerization, bind in a distinct region of the vinca domain. Biochemistry 1995, 34, 9714-9721.

14. Mooberry, S.L.; Tien, G.; Hernandez, A.H.; Plubrukarn, A.; Davidson, B.S. Laulimalide and isolaulimalide, new paclitaxel-like microtubule stabilizing agents. Cancer Res. 1999, 59, 653-660.

15. Bennett, M.J.; Barakat, K.; Huzil, J.T.; Tuszynski, J.; Schriemer, D.C. Discovery and characterization of the laulimalide-microtubule binding mode by mass shift perturbation mapping. Chem. Biol. 2010, 17, 725-734.

16. Watanabe, J.; Natsume, T.; Fujio, N.; Miyasaka, K.; Kobayashi, M. Induction of apoptosis in human cancer cells by TZT-1027, an antimicrotubule agent. Apoptosis 2000, 5, 345-353.

17. Honda-Uezono, A.; Kaida, A.; Michi, Y.; Harada, K.; Hayashi, Y.; Hayashi, Y.; Miura, M. Unusual expression of red, fluorescence at $\mathrm{M}$ phase induced by anti-microtubule agents in $\mathrm{He} \mathrm{La}$ cells expressing the fluorescent ubiquitination-based cell cycle indicator (Fucci). Biochem. Biophys. Res. Commun. 2012, 428, 224-229.

18. Rothmeier, A.S.; Schneiders, U.M.; Wiedmann, R.M.; Ischenko, I.; Bruns, C.J.; Rudy, A.; Zahler, S.; Vollmar, A.M. The marine compound spongistatin 1 targets pancreatic tumor progression and metastasis. Int. J. Cancer 2010, 127, 1096-1105.

19. Bennett, M.J.; Chan, G.K.; Rattner, J.B.; Schriemer, D.C. Low-dose laulimalide represents a novel molecular probe for investigating microtubule organization. Cell Cycle 2012, 11, 3045-3054.

20. Nicholson, B.; Lloyd, G.K.; Miller, B.R.; Palladino, M.A.; Kiso, Y.; Hayashi, Y.; Neuteboom, S.T.C. NPI-2358 is a tubulin-depolymerizing agent: In vitro evidence for activity as a tumor vascular-disrupting agent. Anticancer Drugs 2006, 17, 25-31.

21. Rothmeier, A.S.; Ischenko, I.; Joore, J.; Garczarczyk, D.; Furst, R.; Bruns, C.J.; Vollmar, A.M.; Zahler, S. Investigation of the marine compound spongistatin 1 links the inhibition of PKC $\alpha$ translocation to nonmitotic effects of tubulin antagonism in angiogenesis. FASEB J. 2009, 23, $1127-1137$.

22. Lu, H.Y.; Murtagh, J.; Schwartz, E.L. The microtubule binding drug laulimalide inhibits vascular endothelial growth factor-induced human endothelial cell migration and is synergistic when combined with docetaxel (taxotere). Mol. Pharmacol. 2006, 69, 1207-1215. 
23. Watanabe, J.; Endo, Y.; Shimada, N.; Natsume, T.; Sasaki, T.; Kobayashi, M. Antiangiogenic activity of TZT-1027 (Soblidotin) on chick chorioallantoic membrane and human umbilical vein endothelial cells. In Vivo 2007, 21, 297-304.

24. Otani, M.; Natsume, T.; Watanabe, J.; Kobayashi, M.; Murakoshi, M.; Mikami, T.; Nakayama, T. TZT-1027, an antimicrotubule agent, attacks tumor vasculature and induces tumor cell death. Jpn. J. Cancer Res. 2000, 91, 837-844.

25. Millward, M.; Mainwaring, P.; Mita, A.; Federico, K.; Lloyd, G.K.; Reddinger, N.; Nawrocki, S.; Mita, M.; Spear, M.A. Phase 1 study of the novel vascular disrupting agent plinabulin (NPI-2358) and docetaxel. Invest. New Drugs 2012, 30, 1065-1073.

26. Udagawa, T.; Yuan, J.; Panigrahy, D.; Chang, Y.H.; Shah, J.; D’Amato, R.J. Cytochalasin E, an epoxide containing Aspergillus-derived fungal metabolite, inhibits angiogenesis and tumor growth. J. Pharmacol. Exp. Ther. 2000, 294, 421-427.

27. Duncan, M.D.; Harmon, J.W.; Duncan, K.L.K. Actin disruption inhibits bombesin stimulation of focal adhesion kinase (pp125(FAK)) in prostate carcinoma. J. Surg. Res. 1996, 63, 359-363.

28. Ikewaki, N.; Yamada, A.; Inoko, H. Depolymerization of actin filament by cytochalasin E induces interleukin-8 production and up-regulates CD54 in the HeLa epithelial cell line. Microbiol. Immunol. 2003, 47, 775-783.

29. Cox, A.C. Cytochalasin E enhances the protein kinase C-dependent process of secretion. Biochem. Biophys. Res. Commun. 1988, 150, 745-751.

30. McHardy, L.M.; Sinotte, R.; Troussard, A.; Sheldon, C.; Church, J.; Williams, D.E.; Andersen, R.J.; Dedhar, S.; Roberge, M.; Roskelley, C.D. The tumor invasion inhibitor dihydromotuporamine $\mathrm{C}$ activates $\mathrm{RHO}$, remodels stress fibers and focal adhesions, and stimulates sodium-proton exchange. Cancer Res. 2004, 64, 1468-1474.

31. Roskelley, C.D.; Williams, D.E.; McHardy, L.M.; Leong, K.G.; Troussard, A.; Karsan, A.; Andersen, R.J.; Dedhar, S.; Roberge, M. Inhibition of tumor cell invasion and angiogenesis by motuporamines. Cancer Res. 2001, 61, 6788-6794.

32. Gryder, B.E.; Sodji, Q.H.; Oyelere, A.K. Targeted cancer therapy: Giving histone deacetylase inhibitors all they need to succeed. Future Med. Chem. 2012, 4, 505-524.

33. Fortunati, N.; Catalano, M.G.; Marano, F.; Mugoni, V.; Pugliese, M.; Bosco, O.; Mainini, F.; Boccuzzi, G. The pan-DAC inhibitor LBH589 is a multi-functional agent in breast cancer cells: Cytotoxic drug and inducer of sodium-iodide symporter (NIS). Breast Cancer Res. Treat. 2010, 124, 667-675.

34. Qian, D.Z.; Kato, Y.; Shabbeer, S.; Wei, Y.F.; Verheul, H.M.W.; Salumbides, B.; Sanni, T.; Atadja, P.; Pili, R. Targeting tumor angiogenesis with histone deacetylase inhibitors: The hydroxamic acid derivative LBH589. Clin. Cancer Res. 2006, 12, 634-642.

35. Nakao, Y.; Yoshida, S.; Matsunaga, S.; Shindoh, N.; Terada, Y.; Nagai, K.; Yamashita, J.K.; Ganesan, A.; van Soest, R.W.; Fusetani, N. Azumamides A-E: Histone deacetylase inhibitory cyclic tetrapeptides from the marine sponge Mycale izuensis. Angew. Chem. Int. Ed. Engl. 2006, 45, 7553-7557.

36. Nakao, Y.; Narazaki, G.; Hoshino, T.; Maeda, S.; Yoshida, M.; Maejima, H.; Yamashita, J.K. Evaluation of antiangiogenic activity of azumamides by the in vitro vascular organization model using mouse induced pluripotent stem (iPS) cells. Bioorg. Med. Chem. Lett. 2008, 18, 2982-2984. 
37. Pina, I.C.; Gautschi, J.T.; Wang, G.Y.S.; Sanders, M.L.; Schmitz, F.J.; France, D.; Cornell-Kennon, S.; Sambucetti, L.C.; Remiszewski, S.W.; Perez, L.B.; et al. Psammaplins from the sponge Pseudoceratina purpurea: Inhibition of both histone deacetylase and DNA methyltransferase. J. Org. Chem. 2003, 68, 3866-3873.

38. Shim, J.S.; Lee, H.S.; Shin, J.; Kwon, H.J. Psammaplin A, a marine natural product, inhibits aminopeptidase $\mathrm{N}$ and suppresses angiogenesis in vitro. Cancer Lett. 2004, 203, 163-169.

39. Ahn, M.Y.; Jung, J.H.; Na, Y.J.; Kim, H.S. A natural histone deacetylase inhibitor, Psammaplin A, induces cell cycle arrest and apoptosis in human endometrial cancer cells. Gynecol. Oncol. 2008, $108,27-33$.

40. Kim, D.H.; Shin, J.; Kwon, H.J. Psammaplin A is a natural prodrug that inhibits class I histone deacetylase. Exp. Mol. Med. 2007, 39, 47-55.

41. Mauriz, J.L.; Martin-Renedo, J.; Garcia-Palomo, A.; Tunon, M.J.; Gonzalez-Gallego, J. Methionine aminopeptidases as potential targets for treatment of gastrointestinal cancers and other tumors. Curr. Drug Targets 2010, 11, 1430-1448.

42. Datta, B. Roles of P67/MetAP2 as a tumor suppressor. Biochim. Biophys. Acta 2009, 1796, 281-292.

43. Sato, Y. Role of aminopeptidase in angiogenesis. Biol. Pharm. Bull. 2004, 27, 772-776.

44. Hines, J.; Ju, R.; Dutschman, G.E.; Cheng, Y.C.; Crews, C.M. Reversal of TNP-470-induced endothelial cell growth arrest by guanine and guanine nucleosides. J. Pharmacol. Exp. Ther. 2010, 334, 729-738.

45. Chen, G.J.; Weylie, B.; Hu, C.; Zhu, J.; Forough, R. FGFR1/PI3K/AKT signaling pathway is a novel target for antiangiogenic effects of the cancer drug fumagillin (TNP-470). J. Cell. Biochem. 2007, 101, 1492-1504.

46. Xu, W.; Lu, J.P.; Ye, Q.Z. Structural analysis of bengamide derivatives as inhibitors of methionine aminopeptidases. J. Med. Chem. 2012, 55, 8021-8027.

47. Kinder, F.R.; Versace, R.W.; Bair, K.W.; Bontempo, J.M.; Cesarz, D.; Chen, S.; Crews, P.; Czuchta, A.M.; Jagoe, C.T.; Mou, Y.; et al. Synthesis and antitumor activity of ester-modified analogues of bengamide B. J. Med. Chem. 2001, 44, 3692-3699.

48. Towbin, H.; Bair, K.W.; DeCaprio, J.A.; Eck, M.J.; Kim, S.; Kinder, F.R.; Morollo, A.; Mueller, D.R.; Schindler, P.; Song, H.K.; et al. Proteomics-based target identification: Bengamides as a new class of methionine aminopeptidase inhibitors. J. Biol. Chem. 2003, 278, 52964-52971.

49. Dumez, H.; Gall, H.; Capdeville, R.; Dutreix, C.; van Oosterom, A.T.; Giaccone, G. A phase I and pharmacokinetic study of LAF389 administered to patients with advanced cancer. Anticancer Drugs 2007, 18, 219-225.

50. Castro, M.E.; Gonzalez-Iriarte, M.; Barrero, A.F.; Salvador-Tormo, N.; Munoz-Chapuli, R.; Medina, M.A.; Quesada, A.R. Study of puupehenone and related compounds as inhibitors of angiogenesis. Int. J. Cancer 2004, 110, 31-38.

51. Choi, I.K.; Shin, H.J.; Lee, H.S.; Kwon, H.J. Streptochlorin, a marine natural product, inhibits NF- $\kappa \mathrm{B}$ activation and suppresses angiogenesis in vitro. J. Microbiol. Biotechnol. 2007, 17, $1338-1343$. 
52. Wrasidlo, W.; Mielgo, A.; Torres, V.A.; Barbero, S.; Stoletov, K.; Suyama, T.L.; Klemke, R.L.; Gerwick, W.H.; Carson, D.A.; Stupack, D.G. The marine lipopeptide somocystinamide A triggers apoptosis via caspase 8. Proc. Natl. Acad. Sci. USA 2008, 105, 2313-2318.

53. Aoki, S.; Cho, S.; Ono, M.; Kuwano, T.; Nakao, S.; Kuwano, M.; Nakagawa, S.; Gao, J.Q.; Mayumi, T.; Shibuya, M.; et al. Bastadin 6, a spongean brominated tyrosine derivative, inhibits tumor angiogenesis by inducing selective apoptosis to endothelial cells. Anticancer Drugs 2006, 17, 269-278.

54. Hayashi, A.; Arai, M.; Fujita, M.; Kobayashi, M. Pyripyropenes, fungal sesquiterpenes conjugated with $\alpha$-pyrone and pyridine moieties, exhibits anti-angiogenic activity against human umbilical vein endothelial cells. Biol. Pharm. Bull. 2009, 32, 1261-1265.

55. Aoki, S.; Sanagawa, M.; Watanabe, Y.; Setiawan, A.; Arai, M.; Kobayashi, M. Novel isomarabarican triterpenes, exhibiting selective anti-proliferative activity against vascular endothelial cells, from marine sponge Rhabdastrella globostellata. Bioorg. Med. Chem. 2007, 15, 4818-4828.

56. Shin, H.J.; Kim, T.S.; Lee, H.S.; Park, J.Y.; Choi, I.K.; Kwon, H.J. Streptopyrrolidine, an angiogenesis inhibitor from a marine-derived Streptomyces sp. KORDI-3973. Phytochemistry 2008, 69, 2363-2366.

57. Dias, P.F.; Siqueira, J.M., Jr.; Maraschin, M.; Ferreira, A.G.; Gagliardi, A.R.; Ribeiro-do-Valle, R.M. A polysaccharide isolated from the brown seaweed Sargassum stenophyllum exerts antivasculogenic effects evidenced by modified morphogenesis. Microvasc. Res. 2008, 75 , 34-44.

58. Matsubara, K.; Mori, M.; Matsumoto, H.; Hori, K.; Miyazawa, K. Antiangiogenic properties of a sulfated galactan isolated from a marine green alga, Codium cylindricum. J. Appl. Phycol. 2003, 15, 87-90.

59. Liu, F.; Wang, J.; Chang, A.K.; Liu, B.; Yang, L.L.; Li, Q.M.; Wang, P.S.; Zou, X.Y. Fucoidan extract derived from Undaria pinnatifida inhibits angiogenesis by human umbilical vein endothelial cells. Phytomedicine 2012, 19, 797-803.

60. Xue, M.; Ge, Y.; Zhang, J.; Wang, Q.; Hou, L.; Liu, Y.; Sun, L.; Li, Q. Anticancer properties and mechanisms of fucoidan on mouse breast cancer in vitro and in vivo. PLoS One 2012, 7, e43483.

61. Chittiboyina, A.G.; Kumar, G.M.; Carvalho, P.B.; Liu, Y.; Zhou, Y.D.; Nagle, D.G.; Avery, M.A. Total synthesis and absolute configuration of laurenditerpenol: A hypoxia inducible factor-1 activation inhibitor. J. Med. Chem. 2007, 50, 6299-6302.

62. Arafeh, K.M.; Ullah, N. Synthesis of neolamellarin A, an inhibitor of hypoxia-inducible factor-1. Nat. Prod. Commun. 2009, 4, 925-926.

63. Taraboletti, G.; Poli, M.; Dossi, R.; Manenti, L.; Borsotti, P.; Faircloth, G.T.; Broggini, M.; D'Incalci, M.; Ribatti, D.; Giavazzi, R. Antiangiogenic activity of aplidine, a new agent of marine origin. Br. J. Cancer 2004, 90, 2418-2424.

64. Straight, A.M.; Oakley, K.; Moores, R.; Bauer, A.J.; Patel, A.; Tuttle, R.M.; Jimeno, J.; Francis, G.L. Aplidin reduces growth of anaplastic thyroid cancer xenografts and the expression of several angiogenic genes. Cancer Chemother. Pharmacol. 2006, 57, 7-14. 
65. Caers, J.; Menu, E.; de Raeve, H.; Lepage, D.; van Valckenborgh, E.; van Camp, B.; Alvarez, E.; Vanderkerken, K. Antitumour and antiangiogenic effects of Aplidin in the 5TMM syngeneic models of multiple myeloma. Br. J. Cancer 2008, 98, 1966-1974.

66. Sills, A.K.; Williams, J.I.; Tyler, B.M.; Epstein, D.S.; Sipos, E.P.; Davis, J.D.; McLane, M.P.; Pitchford, S.; Cheshire, K.; Cannon, F.H.; et al. Squalamine inhibits angiogenesis and solid tumor growth in vivo and perturbs embryonic vasculature. Cancer Res. 1998, 58, 2784-2792.

67. Ciulla, T.A.; Criswell, M.H.; Danis, R.P.; Williams, J.I.; McLane, M.P.; Holroyd, K.J. Squalamine lactate reduces choroidal neovascularization in a laser-injury model in the rat. Retina 2003, 23, 808-814.

68. Hao, D.; Hammond, L.A.; Eckhardt, S.G.; Patnaik, A.; Takimoto, C.H.; Schwartz, G.H.; Goetz, A.D.; Tolcher, A.W.; McCreery, H.A.; Mamun, K.; et al. A phase I and pharmacokinetic study of squalamine, an aminosterol angiogenesis inhibitor. Clin. Cancer Res. 2003, 9, 2465-2471.

69. Walker, B.T.; Houston, T.A. Squalamine and its derivatives as potential antitubercular compounds. Tuberculosis 2012, 93, 102-103.

70. Hraiech, S.; Bregeon, F.; Brunel, J.M.; Rolain, J.M.; Lepidi, H.; Andrieu, V.; Raoult, D.; Papazian, L.; Roch, A. Antibacterial efficacy of inhaled squalamine in a rat model of chronic Pseudomonas aeruginosa pneumonia. J. Antimicrob. Chemother. 2012, 67, 2452-2458.

71. Feling, R.H.; Buchanan, G.O.; Mincer, T.J.; Kauffman, C.A.; Jensen, P.R.; Fenical, W. Salinosporamide A: A highly cytotoxic proteasome inhibitor from a novel microbial source, a marine bacterium of the new genus salinospora. Angew. Chem. Int. Ed. Engl. 2003, 42, 355-357.

72. Chauhan, D.; Catley, L.; Li, G.; Podar, K.; Hideshima, T.; Velankar, M.; Mitsiades, C.; Mitsiades, N.; Yasui, H.; Letai, A.; et al. A novel orally active proteasome inhibitor induces apoptosis in multiple myeloma cells with mechanisms distinct from Bortezomib. Cancer Cell 2005, 8, 407-419.

73. Ahn, K.S.; Sethi, G.; Chao, T.H.; Neuteboom, S.T.C.; Chaturvedi, M.M.; Palladino, M.A.; Younes, A.; Aggarwal, B.B. Salinosporamide A (NPI-0052) potentiates apoptosis, suppresses osteoclastogenesis, and inhibits invasion through down-modulation of NF-kB-regulated gene products. Blood 2007, 110, 2286-2295.

74. Zhu, K.Y.; Chan, W.; Heymach, J.; Wilkinson, M.; McConkey, D.J. Control of HIF-1 $\alpha$ expression by eIF2 $\alpha$ phosphorylation-mediated translational repression. Cancer Res. 2009, 69, 1836-1843.

75. Irie, K.; Yanagita, R.C.; Nakagawa, Y. Challenges to the development of bryostatin-type anticancer drugs based on the activation mechanism of protein kinase C $\delta$. Med. Res. Rev. 2012, 32, $518-535$.

76. Kazanietz, M.G.; Lewin, N.E.; Gao, F.; Pettit, G.R.; Blumberg, P.M. Binding of [26-3H]bryostatin 1 and analogs to calcium-dependent and calcium-independent protein kinase $\mathrm{C}$ isozymes. Mol. Pharmacol. 1994, 46, 374-379.

77. Szallasi, Z.; Denning, M.F.; Smith, C.B.; Dlugosz, A.A.; Yuspa, S.H.; Pettit, G.R.; Blumberg, P.M. Bryostatin 1 protects protein kinase $\mathrm{C}-\delta$ from down-regulation in mouse keratinocytes in parallel with its inhibition of phorbol ester-induced differentiation. Mol. Pharmacol. 1994, 46, 840-850. 
78. Szallasi, Z.; Smith, C.B.; Pettit, G.R.; Blumberg, P.M. Differential regulation of protein kinase C isozymes by bryostatin 1 and phorbol 12-myristate 13-acetate in NIH 3T3 fibroblasts. J. Biol. Chem. 1994, 269, 2118-2124.

79. Nezhat, F.; Wadler, S.; Muggia, F.; Mandeli, J.; Goldberg, G.; Rahaman, J.; Runowicz, C.; Murgo, A.J.; Gardner, G.J. Phase II trial of the combination of bryostatin-1 and cisplatin in advanced or recurrent carcinoma of the cervix: A New York Gynecologic Oncology Group study. Gynecol. Oncol. 2004, 93, 144-148.

80. Mackay, H.J.; Twelves, C.J. Targeting the protein kinase C family: Are we there yet? Nat. Rev. Cancer 2007, 7, 554-562.

81. Shafiq, M.I.; Steinbrecher, T.; Schmid, R. FASCAPLYSIN as a specific inhibitor for CDK4: Insights from molecular modelling. PLoS One 2012, 7, e42612.

82. Zheng, Y.L.; Lu, X.L.; Lin, J.; Chen, H.M.; Yan, X.J.; Wang, F.; Xu, W.F. Direct effects of fascaplysin on human umbilical vein endothelial cells attributing the anti-angiogenesis activity. Biomed. Pharmacother. 2010, 64, 527-533.

83. Yan, X.J.; Chen, H.M.; Lu, X.L.; Wang, F.; Xu, W.F.; Jin, H.X.; Zhu, P. Fascaplysin exert anti-tumor effects through apoptotic and anti-angiogenesis pathways in sarcoma mice model. Eur. J. Pharm. Sci. 2011, 43, 251-259.

84. Lin, J.; Yan, X.J.; Chen, H.M. Fascaplysin, a selective CDK4 inhibitor, exhibit anti-angiogenic activity in vitro and in vivo. Cancer Chemother. Pharmacol. 2007, 59, 439-445.

85. Aoki, S.; Watanabe, Y.; Sanagawa, M.; Setiawan, A.; Kotoku, N.; Kobayashi, M. Cortistatins A, $\mathrm{B}, \mathrm{C}$, and D, anti-angiogenic steroidal alkaloids, from the marine sponge Corticium simplex. J. Am. Chem. Soc. 2006, 128, 3148-3149.

86. Aoki, S.; Watanabe, Y.; Tanabe, D.; Arai, M.; Suna, H.; Miyamoto, K.; Tsujibo, H.; Tsujikawa, K.; Yamamoto, H.; Kobayashi, M. Structure-activity relationship and biological property of cortistatins, anti-angiogenic spongean steroidal alkaloids. Bioorg. Med. Chem. 2007, 15, 6758-6762.

87. Cee, V.J.; Chen, D.Y. K.; Lee, M.R.; Nicolaou, K.C. Cortistatin A is a high-affinity ligand of protein kinases ROCK, CDK8, and CDK11. Angew. Chem. Int. Ed. Engl. 2009, 48, 8952-8957.

88. Dupont, E.; Falardeau, P.; Mousa, S.A.; Dimitriadou, V.; Pepin, M.C.; Wang, T.Q.; Alaoui-Jamali, M.A. Antiangiogenic and antimetastatic properties of Neovastat (AE-941), an orally active extract derived from cartilage tissue. Clin. Exp. Metastas 2002, 19, 145-153.

89. Beliveau, R.; Gingras, D.; Kruger, E.A.; Lamy, S.; Sirois, P.; Tranqui, L.; Baffert, F.; Beaulieu, E.; Dimitriadou, V.; Pepin, M.C.; et al. The antiangiogenic agent Neovastat (AE-941) inhibits vascular endothelial growth factor-mediated biological effects. Clin. Cancer Res. 2002, 8, 1242-1250.

90. Gingras, D.; Renaud, A.; Mousseau, N.; Beaulieu, E.; Kachra, Z.; Beliveau, R. Matrix proteinase inhibition by AE-941, a multifunctional antiangiogenic compound. Anticancer Res. 2001, 21, 145-155.

91. Gingras, D.; Labelle, D.; Nyalendo, C.; Boivin, D.; Demeule, M.; Barthomeuf, C.; Beliveau, R. The antiangiogenic agent Neovastat (AE-941) stimulates tissue plasminogen activator activity. Invest. New Drugs 2004, 22, 17-26. 
92. Boivin, D.; Gendron, S.; Beaulieu, E.; Gingras, D.; Beliveau, R. The antiangiogenic agent Neovastat (AE-941) induces endothelial cell apoptosis. Mol. Cancer Ther. 2002, 1, 795-802.

93. Falardeau, P.; Champagne, P.; Poyet, P.; Hariton, C.; Dupont, E. Neovastat, a naturally occurring multifunctional antiangiogenic drug, in phase III clinical trials. Semin. Oncol. 2001, 28, 620-625.

94. Lu, C.; Lee, J.J.; Komaki, R.; Herbst, R.S.; Feng, L.; Evans, W.K.; Choy, H.; Desjardins, P.; Esparaz, B.T.; Truong, M.T.; et al. Chemoradiotherapy with or without AE-941 in stage III non-small cell lung cancer: A randomized phase III trial. J. Natl. Cancer Inst. 2010, 102, 859-865.

95. Escudier, B.; Choueiri, T.K.; Oudard, S.; Szczylik, C.; Negrier, S.; Ravaud, A.; Chevreau, C.; Venner, P.; Champagne, P.; Croteau, D.; et al. Prognostic factors of metastatic renal cell carcinoma after failure of immunotherapy: New paradigm from a large phase III trial with shark cartilage extract AE 941. J. Urol. 2007, 178, 1901-1905.

96. Sharma, M.R.; Karrison, T.G.; Jin, Y.; Bies, R.R.; Maitland, M.L.; Stadler, W.M.; Ratain, M.J. Resampling phase III data to assess phase II trial designs and endpoints. Clin. Cancer Res. 2012, 18, 2309-2315.

97. Alifrangis, C.; Stebbing, J. Shark cartilage: Has the popularisation of science failed? Lancet Oncol. 2012, 13, 22-22.

98. Martinez-Poveda, B.; Rodriguez-Nieto, S.; Garcia-Caballero, M.; Medina, M.A.; Quesada, A.R. The antiangiogenic compound aeroplysinin-1 induces apoptosis in endothelial cells by activating the mitochondrial pathway. Mar. Drugs 2012, 10, 2033-2046.

99. Hinterding, K.; Knebel, A.; Herrlich, P.; Waldmann, H. Synthesis and biological evaluation of aeroplysinin analogues: A new class of receptor tyrosine kinase inhibitors. Bioorg. Med. Chem. 1998, 6, 1153-1162.

100. Sallam, A.A.; Ramasahayam, S.; Meyer, S.A.; Sayed, K.A. Design, synthesis, and biological evaluation of dibromotyrosine analogues inspired by marine natural products as inhibitors of human prostate cancer proliferation, invasion, and migration. Bioorg. Med. Chem. 2010, 18, 7446-7457.

101. Tong, Y.G.; Zhang, X.W.; Tian, F.; Yi, Y.H.; Xu, Q.Z.; Li, L.; Tong, L.J.; Lin, L.P.; Ding, J. Philinopside A, a novel marine-derived compound possessing dual anti-angiogenic and anti-tumor effects. Int. J. Cancer 2005, 114, 843-853.

102. Tian, F.; Zhang, X.W.; Tong, Y.G.; Yi, Y.; Zhang, S.L.; Li, L.; Sun, P.; Lin, L.P.; Ding, J. PE, a new sulfated saponin from sea cucumber, exhibits anti-angiogenic and anti-tumor activities in vitro and in vivo. Cancer Biol. Ther. 2005, 4, 874-882.

103. Shengule, S.R.; Loa-Kum-Cheung, W.L.; Parish, C.R.; Blairvacq, M.; Meijer, L.; Nakao, Y.; Karuso, P. A one-pot synthesis and biological activity of ageladine a and analogues. J. Med. Chem. 2011, 54, 2492-2503.

104. Ando, N.; Terashima, S. Synthesis and matrix metalloproteinase (MMP)-12 inhibitory activity of ageladine A and its analogs. Bioorg. Med. Chem. Lett. 2007, 17, 4495-4499.

105. Meketa, M.L.; Weinreb, S.M.; Nakao, Y.; Fusetani, N. Application of a 6pi-1-azatriene electrocyclization strategy to the total synthesis of the marine sponge metabolite ageladine $\mathrm{A}$ and biological evaluation of synthetic analogues. J. Org. Chem. 2007, 72, 4892-4899.

106. Shengule, S.R.; Karuso, P. Concise total synthesis of the marine natural product ageladine A. Org. Lett. 2006, 8, 4083-4084. 
107. Meketa, M.L.; Weinreb, S.M. Total synthesis of ageladine A, an angiogenesis inhibitor from the marine sponge Agelas nakamurai. Org. Lett. 2006, 8, 1443-1446.

108. Fujita, M.; Nakao, Y.; Matsunaga, S.; Seiki, M.; Itoh, Y.; Yamashita, J.; van Soest, R.W.M.; Fusetani, N. Bioactive marine metabolites, Part 124. Ageladine A: An antiangiogenic matrixmetalloproteinase inhibitor from the marine sponge Agelas nakamurai. J. Am. Chem. Soc. 2003, 125, 15700-15701.

109. Obermann, D.; Bickmeyer, U.; Wagele, H. Incorporated nematocysts in Aeolidiella stephanieae (Gastropoda, Opisthobranchia, Aeolidoidea) mature by acidification shown by the $\mathrm{pH}$ sensitive fluorescing alkaloid Ageladine A. Toxicon 2012, 60, 1108-1116.

110. Bickmeyer, U. The alkaloid Ageladine A, originally isolated from marine sponges, used for pH-sensitive imaging of transparent marine animals. Mar. Drugs 2012, 10, 223-233.

111. Zhao, H.J.; Liu, H.Y.; Chen, Y.; Xin, X.L.; Li, J.; Hou, Y.T.; Zhang, Z.H.; Zhang, X.W.; Me, C.Y.; Geng, M.Y.; et al. Oligomannurarate sulfate, a novel heparanase inhibitor simultaneously targeting basic fibroblast growth factor, combats tumor angiogenesis and metastasis. Cancer Res. 2006, 66, 8779-8787.

112. Ma, J.G.; Xin, X.L.; Meng, L.H.; Tong, L.J.; Lin, L.P.; Geng, M.Y.; Ding, J. The marine-derived oligosaccharide sulfate (MdOS), a novel multiple tyrosine kinase inhibitor, combats tumor angiogenesis both in vitro and in vivo. PLoS One 2008, 3, e3774.

113. Chabut, D.; Fischer, A.M.; Colliec-Jouault, S.; Laurendeau, I.; Matou, S.; Le Bonniec, B.; Helley, D. Low molecular weight fucoidan and heparin enhance the basic fibroblast growth factor-induced tube formation of endothelial cells through heparan sulfate-dependent $\alpha 6$ overexpression. Mol. Pharmacol. 2003, 64, 696-702.

114. Lake, A.C.; Vassy, R.; Di Benedetto, M.; Lavigne, D.; Le Visage, C.; Perret, G.Y.; Letourneur, D. Low molecular weight fucoidan increases VEGF(165)-induced endothelial cell migration by enhancing VEGF(165) binding to VEGFR-2 and NRP1. J. Biol. Chem. 2006, 281, 37844-37852.

115. Luyt, C.E.; Meddahi-Pelle, A.; Ho-Tin-Noe, B.; Colliec-Jouault, S.; Guezennec, J.; Louedec, L.; Prats, H.E.; Jacob, M.P.; Osborne-Pellegrin, M.; Letourneur, D.; et al. Low-molecular-weight fucoidan promotes therapeutic revascularization in a rat model of critical hindlimb ischemia. J. Pharmacol. Exp. Ther. 2003, 305, 24-30.

116. Matsubara, K.; Xue, C.; Zhao, X.; Mori, M.; Sugawara, T.; Hirata, T. Effects of middle molecular weight fucoidans on in vitro and ex vivo angiogenesis of endothelial cells. Int. J. Mol. Med. 2005, 15, 695-699.

117. Cumashi, A.; Ushakova, N.A.; Preobrazhenskaya, M.E.; D’Incecco, A.; Piccoli, A.; Totani, L.; Tinari, N.; Morozevich, G.E.; Berman, A.E.; Bilan, M.I.; et al. A comparative study of the anti-inflammatory, anticoagulant, antiangiogenic, and antiadhesive activities of nine different fucoidans from brown seaweeds. Glycobiology 2007, 17, 541-552.

118. Soeda, S.; Kozako, T.; Iwata, K.; Shimeno, H. Oversulfated fucoidan inhibits the basic fibroblast growth factor-induced tube formation by human umbilical vein endothelial cells: Its possible mechanism of action. Biochim. Biophys. Acta 2000, 1497, 127-134.

119. Koyanagi, S.; Tanigawa, N.; Nakagawa, H.; Soeda, S.; Shimeno, H. Oversulfation of fucoidan enhances its anti-angiogenic and antitumor activities. Biochem. Pharmacol. 2003, 65, 173-179. 
120. Dias, P.F.; Siqueira, J.M.; Vendruscolo, L.F.; Neiva, T.D.; Gagliardi, A.R.; Maraschin, M.; Ribeiro-do-Valle, R.M. Antiangiogenic and antitumoral properties of a polysaccharide isolated from the seaweed Sargassum stenophyllum. Cancer Chemother. Pharmacol. 2005, 56, 436-446.

121. Tang, X.L.; Li, J.; Xin, X.L.; Geng, M.Y. A new marine-derived sulfated polysaccharide from brown alga suppresses tumor metastasis both in vitro and in vivo. Cancer Biol. Ther. 2006, 5, 1474-1480.

122. Abdel-Lateff, A.; Klemke, C.; Konig, G.M.; Wright, A.D. Two new xanthone derivatives from the algicolous marine fungus Wardomyces anomalus. J. Nat. Prod. 2003, 66, 706-708.

123. Ebada, S.S.; Schulz, B.; Wray, V.; Totzke, F.; Kubbutat, M.H.G.; Muller, W.E.G.; Hamacher, A.; Kassack, M.U.; Lin, W.H.; Proksch, P. Arthrinins A-D: Novel diterpenoids and further constituents from the sponge derived fungus Arthrinium sp. Bioorg. Med. Chem. 2011, 19, 4644-4651.

124. Ohkawa, Y.; Miki, K.; Suzuki, T.; Nishio, K.; Sugita, T.; Kinoshita, K.; Takahashi, K.; Koyama, K. Antiangiogenic metabolites from a marine-derived fungus, Hypocrea vinosa. J. Nat. Prod. 2010, 73, 579-582.

125. Patel, S.; Keohan, M.L.; Saif, M.W.; Rushing, D.; Baez, L.; Feit, K.; DeJager, R.; Anderson, S. Phase II study of intravenous TZT-1027 in patients with advanced or metastatic soft-tissue sarcomas with prior exposure to anthracycline-based chemotherapy. Cancer 2006, 107, 2881-2887.

126. Riely, G.J.; Gadgeel, S.; Rothman, I.; Saidman, B.; Sabbath, K.; Feit, K.; Kris, M.G.; Rizvi, N.A. A phase 2 study of TZT-1027, administered weekly to patients with advanced non-small cell lung cancer following treatment with platinum-based chemotherapy. Lung Cancer 2007, 55, 181-185.

127. Logothetis, C.J.; Wu, K.K.; Finn, L.D.; Daliani, D.; Figg, W.; Ghaddar, H.; Gutterman, J.U. Phase I trial of the angiogenesis inhibitor TNP-470 for progressive androgen-independent prostate cancer. Clin. Cancer Res. 2001, 7, 1198-1203.

128. Folkman, J. Angiogenesis. Annu. Rev. Med. 2006, 57, 1-18.

129. Herbst, R.S.; Hammond, L.A.; Carbone, D.P.; Tran, H.T.; Holroyd, K.J.; Desai, A.; Williams, J.I.; Bekele, B.N.; Hait, H.; Allgood, V.; et al. A phase I/IIA trial of continuous five-day infusion of squalamine lactate (MSI-1256F) plus carboplatin and paclitaxel in patients with advanced non-small cell lung cancer. Clin. Cancer Res. 2003, 9, 4108-4115.

130. Varterasian, M.L.; Mohammad, R.M.; Shurafa, M.S.; Hulburd, K.; Pemberton, P.A.; Rodriguez, D.H.; Spadoni, V.; Eilender, D.S.; Murgo, A.; Wall, N.; et al. Phase II trial of bryostatin 1 in patients with relapsed low-grade non-Hodgkin's lymphoma and chronic lymphocytic leukemia. Clin. Cancer Res. 2000, 6, 825-828.

131. Pagliaro, L.; Daliani, D.; Amato, R.; Tu, S.M.; Jones, D.; Smith, T.; Logothetis, C.; Millikan, R. A phase II trial of bryostatin-1 for patients with metastatic renal cell carcinoma. Cancer 2000, 89, 615-618.

132. Zonder, J.A.; Shields, A.F.; Zalupski, M.; Chaplen, R.; Heilbrun, L.K.; Arlauskas, P.; Philip, P.A. A phase II trial of bryostatin 1 in the treatment of metastatic colorectal cancer. Clin. Cancer Res. 2001, 7, 38-42. 
133. Blackhall, F.H.; Ranson, M.; Radford, J.A.; Hancock, B.W.; Soukop, M.; McGown, A.T.; Robbins, A.; Halbert, G.; Jayson, G.C.; Comm, C.R.; et al. A phase II trial of bryostatin 1 in patients with non-Hodgkin's lymphoma. Br. J. Cancer 2001, 84, 465-469.

134. Bedikian, A.Y.; Plager, C.; Stewart, J.R.; O’Brian, C.A.; Herdman, S.K.; Ross, M.; Papadopoulos, N.; Eton, O.; Ellerhorst, J.; Smith, T. Phase II evaluation of bryostatin-1 in metastatic melanoma. Melanoma Res. 2001, 11, 183-188.

135. Varterasian, M.L.; Pemberton, P.A.; Hulburd, K.; Rodriguez, D.H.; Murgo, A.; Al-Katib, A.M. Phase II study of bryostatin 1 in patients with relapsed multiple myeloma. Invest. New Drugs 2001, 19, 245-247.

136. Brockstein, B.; Samuels, B.; Humerickhouse, R.; Arietta, R.; Fishkin, P.; Wade, J.; Sosman, J.; Vokes, E.E. Phase II studies of bryostatin-1 in patients with advanced sarcoma and advanced head and neck cancer. Invest. New Drugs 2001, 19, 249-254.

137. Pfister, D.G.; McCaffrey, J.; Zahalsky, A.J.; Schwartz, G.K.; Lis, E.; Gerald, W.; Huvos, A.; Shah, J.; Kraus, D.; Shaha, A.; et al. A phase II trial of bryostatin-1 in patients with metastatic or recurrent squamous cell carcinoma of the head and neck. Invest. New Drugs 2002, 20, 123-127.

138. Tozer, R.G.; Burdette-Radoux, S.; Berlanger, K.; Davis, M.L.; Lohmann, R.C.; Rusthoven, J.R.; Wainman, N.; Zee, B.; Seymour, L. A randomized phase II study of two schedules of bryostatin-1 (NSC339555) in patients with advanced malignant melanoma: A National Cancer Institute of Canada Clinical Trials Group study. Invest. New Drugs 2002, 20, 407-412.

139. Haas, N.B.; Smith, M.; Lewis, N.; Littman, L.; Yeslow, G.; Joshi, I.D.; Murgo, A.; Bradley, J.; Gordon, R.; Wang, H.; et al. Weekly bryostatin-1 in metastatic renal cell carcinoma: A phase II study. Clin. Cancer Res. 2003, 9, 109-114.

140. Winegarden, J.D.; Mauer, A.M.; Gajewski, T.F.; Hoffman, P.C.; Krauss, S.; Rudin, C.M.; Vokes, E.E. A phase II study of bryostatin-1 and paclitaxel in patients with advanced non-small cell lung cancer. Lung Cancer 2003, 39, 191-196.

141. Clamp, A.R.; Blackhall, F.H.; Vasey, P.; Soukop, M.; Coleman, R.; Halbert, G.; Robson, L.; Jayson, G.C. A phase II trial of bryostatin-1 administered by weekly 24 -hour infusion in recurrent epithelial ovarian carcinoma. Br. J. Cancer 2003, 89, 1152-1154.

142. Madhusudan, S.; Protheroe, A.; Propper, D.; Han, C.; Corrie, P.; Earl, H.; Hancock, B.; Vasey, P.; Turner, A.; Balkwill, F.; et al. A multicentre phase II trial of bryostatin-1 in patients with advanced renal cancer. Br. J. Cancer 2003, 89, 1418-1422.

143. Armstrong, D.K.; Blessing, J.A.; Look, K.Y.; Schilder, R.; Nunez, E.R. A randomized phase II evaluation of bryostatin-1 (NSC \#339555) in recurrent or persistent platinum-sensitive ovarian cancer: A Gynecologic Oncology Group Study. Invest. New Drugs 2003, 21, 373-377.

144. Armstrong, D.K.; Blessing, J.A.; Rader, J.; Sorosky, J.I. A randomized phase II evaluation of bryostatin-1 (NSC \#339555) in persistent or recurrent squamous cell carcinoma of the cervix: A Gynecologic Oncology Group Study. Invest. New Drugs 2003, 21, 453-457.

145. Peterson, A.C.; Harlin, H.; Karrison, T.; Vogelzang, N.J.; Knost, J.A.; Kugler, J.W.; Lester, E.; Vokes, E.; Gajewski, T.F.; Stadler, W.M. A randomized phase II trial of interleukin-2 in combination with four different doses of bryostatin-1 in patients with renal cell carcinoma. Invest. New Drugs 2006, 24, 141-149. 
146. Ajani, J.A.; Jiang, Y.; Faust, J.; Chang, B.B.; Ho, L.; Yao, J.C.; Rousey, S.; Dakhil, S.; Cherny, R.C.; Craig, C.; Bleyer, A. A multi-center phase II study of sequential paclitaxel and bryostatin-1 (NSC 339555) in patients with untreated, advanced gastric or gastroesophageal junction adenocarcinoma. Invest. New Drugs 2006, 24, 353-357.

147. Ku, G.Y.; Ilson, D.H.; Schwartz, L.H.; Capanu, M.; O’Reilly, E.; Shah, M.A.; Kelsen, D.P.; Schwartz, G.K. Phase II trial of sequential paclitaxel and $1 \mathrm{~h}$ infusion of bryostatin-1 in patients with advanced esophageal cancer. Cancer Chemother. Pharmacol. 2008, 62, 875-880.

148. Barr, P.M.; Lazarus, H.M.; Cooper, B.W.; Schluchter, M.D.; Panneerselvam, A.; Jacobberger, J.W.; Hsu, J.W.; Janakiraman, N.; Simic, A.; Dowlati, A.; et al. Phase II study of bryostatin 1 and vincristine for aggressive non-Hodgkin lymphoma relapsing after an autologous stem cell transplant. Am. J. Hematol. 2009, 84, 484-487.

149. Lam, A.P.; Sparano, J.A.; Vinciguerra, V.; Ocean, A.J.; Christos, P.; Hochster, H.; Camacho, F.; Goel, S.; Mani, S.; Kaubisch, A. Phase II study of paclitaxel plus the protein kinase C inhibitor bryostatin-1 in advanced pancreatic carcinoma. Am. J. Clin. Oncol. 2010, 33, 121-124.

150. Morgan, R.J., Jr.; Leong, L.; Chow, W.; Gandara, D.; Frankel, P.; Garcia, A.; Lenz, H.J.; Doroshow, J.H. Phase II trial of bryostatin-1 in combination with cisplatin in patients with recurrent or persistent epithelial ovarian cancer: A California cancer consortium study. Invest. New Drugs 2012, 30, 723-728.

151. Clamp, A.; Jayson, G.C. The clinical development of the bryostatins. Anticancer Drugs 2002, 13, 673-683.

152. Hale, K.J.; Hummersone, M.G.; Manaviazar, S.; Frigerio, M. The chemistry and biology of the bryostatin antitumour macrolides. Nat. Prod. Rep. 2002, 19, 413-453.

153. Hideshima, T.; Richardson, P.G.; Anderson, K.C. Mechanism of action of proteasome inhibitors and deacetylase inhibitors and the biological basis of synergy in multiple myeloma. Mol. Cancer Ther. 2011, 10, 2034-2042.

154.ClinicalTrials.gov. Available on line: http://clinicaltrials.gov/ct2/results?term=panobinostat\& Search=Search (accessed on 1 February 2013).

155. Hainsworth, J.D.; Infante, J.R.; Spigel, D.R.; Arrowsmith, E.R.; Boccia, R.V.; Burris, H.A. A phase II trial of panobinostat, a histone deacetylase inhibitor, in the treatment of patients with refractory metastatic renal cell carcinoma. Cancer Invest. 2011, 29, 451-455.

156. Dimicoli, S.; Jabbour, E.; Borthakur, G.; Kadia, T.; Estrov, Z.; Yang, H.; Kelly, M.; Pierce, S.; Kantarjian, H.; Garcia-Manero, G. Phase II study of the histone deacetylase inhibitor panobinostat (LBH589) in patients with low or intermediate-1 risk myelodysplastic syndrome. Am. J. Hematol. 2012, 87, 127-129.

157. Wolf, J.L.; Siegel, D.; Goldschmidt, H.; Hazell, K.; Bourquelot, P.M.; Bengoudifa, B.R.; Matous, J.; Vij, R.; de Magalhaes-Silverman, M.; Abonour, R.; et al. Phase II trial of the pan-deacetylase inhibitor panobinostat as a single agent in advanced relapsed/refractory multiple myeloma. Leuk. Lymphoma 2012, 53, 1820-1823.

158. Offidani, M.; Polloni, C.; Cavallo, F.; Liberati, A.M.; Ballanti, S.; Pulini, S.; Catarini, M.; Alesiani, F.; Corvatta, L.; Gentili, S.; et al. Phase II study of melphalan, thalidomide and prednisone combined with oral panobinostat in patients with relapsed/refractory multiple myeloma. Leuk. Lymphoma 2012, 53, 1722-1727. 
159. Wang, H.B.; Cao, Q.; Dudek, A.Z. Phase II study of panobinostat and bortezomib in patients with pancreatic cancer progressing on gemcitabine-based therapy. Anticancer Res. 2012, 32, 1027-1031.

160. Younes, A.; Sureda, A.; Ben-Yehuda, D.; Zinzani, P.L.; Ong, T.C.; Prince, H.M.; Harrison, S.J.; Kirschbaum, M.; Johnston, P.; Gallagher, J.; et al. Panobinostat in patients with relapsed/refractory Hodgkin's Lymphoma after autologous stem-cell transplantation: Results of a phase II study. J. Clin. Oncol. 2012, 30, 2197-2203.

161. Duvic, M.; Dummer, R.; Becker, J.C.; Poulalhon, N.; Ortiz Romero, P.; Grazia Bernengo, M.; Lebbe, C.; Assaf, C.; Squier, M.; Williams, D.; et al. Panobinostat activity in both bexarotene-exposed and -naive patients with refractory cutaneous T-cell lymphoma: Results of a phase II trial. Eur. J. Cancer 2013, 49, 386-394.

162. Ghobrial, I.M.; Campigotto, F.; Murphy, T.J.; Boswell, E.N.; Banwait, R.; Azab, F.; Chuma, S.; Kunsman, J.; Donovan, A.; Masood, F.; et al. Results of the phase II trial of single agent histone deacetylase inhibitor panobinostat in patients with relapsed/refractory Waldenstrom macroglobulinemia. Blood 2013, 121, 1296-1303.

163. Jones, S.F.; Infante, J.R.; Thompson, D.S.; Mohyuddin, A.; Bendell, J.C.; Yardley, D.A.; Burris, H.A., III. A phase I trial of oral administration of panobinostat in combination with paclitaxel and carboplatin in patients with solid tumors. Cancer Chemother. Pharmacol. 2012, 70, 471-475.

164. Strickler, J.H.; Starodub, A.N.; Jia, J.; Meadows, K.L.; Nixon, A.B.; Dellinger, A.; Morse, M.A.; Uronis, H.E.; Marcom, P.K.; Zafar, S.Y.; et al. Phase I study of bevacizumab, everolimus, and panobinostat (LBH-589) in advanced solid tumors. Cancer Chemother. Pharmacol. 2012, 70, 251-258.

165. Prince, H.M.; Bishton, M.J.; Harrison, S.J. Clinical studies of histone deacetylase inhibitors. Clin. Cancer Res. 2009, 15, 3958-3969.

166. Barboza, N.M.; Medina, D.J.; Budak-Alpdogan, T.; Aracil, M.; Jimeno, J.M.; Bertino, J.R.; Banerjee, D. Plitidepsin (Aplidin) is a potent inhibitor of diffuse large cell and Burkitt lymphoma and is synergistic with rituximab. Cancer Biol. Ther. 2012, 13, 114-122.

167. Soto-Matos, A.; Szyldergemajn, S.; Extremera, S.; Miguel-Lillo, B.; Alfaro, V.; Coronado, C.; Lardelli, P.; Roy, E.; Corrado, C.S.; Kahatt, C. Plitidepsin has a safe cardiac profile: A comprehensive analysis. Mar. Drugs 2011, 9, 1007-1023.

168. Geoerger, B.; Estlin, E.J.; Aerts, I.; Kearns, P.; Gibson, B.; Corradini, N.; Doz, F.; Lardelli, P.; Miguel, B.D.; Soto, A.; et al. A phase I and pharmacokinetic study of plitidepsin in children with advanced solid tumours: An Innovative Therapies for Children with Cancer (ITCC) study. Eur. J. Cancer 2012, 48, 289-296.

169. Schoffski, P.; Guillem, V.; Garcia, M.; Rivera, F.; Tabernero, J.; Cullell, M.; Lopez-Martin, J.A.; Pollard, P.; Dumez, H.; del Muro, X.G.; et al. Phase II randomized study of Plitidepsin (Aplidin), alone or in association with L-carnitine, in patients with unresectable advanced renal cell carcinoma. Mar. Drugs 2009, 7, 57-70.

170. Le Tourneau, C.; Raymond, E.; Faivre, S. Aplidine: A paradigm of how to handle the activity and toxicity of a novel marine anticancer poison. Curr. Pharm. Des. 2007, 13, 3427-3439. 
171. Jimeno, J.; Lopez-Martin, J.A.; Ruiz-Casado, A.; Izquierdo, M.A.; Scheuer, P.J.; Rinehart, K. Progress in the clinical development of new marine-derived anticancer compounds. Anticancer Drugs 2004, 15, 321-329.

172. Baudin, E.; Droz, J.P.; Paz-Ares, L.; van Oosterom, A.T.; Cullell-Young, M.; Schlumberger, M. Phase II study of plitidepsin 3-hour infusion every 2 weeks in patients with unresectable advanced medullary thyroid carcinoma. Am. J. Clin. Oncol. 2010, 33, 83-88.

173. Eisen, T.; Thomas, J.; Miller, W.H.; Gore, M.; Wolter, P.; Kavan, P.; Martin, J.A. L.; Lardelli, P. Phase II study of biweekly plitidepsin as second-line therapy in patients with advanced malignant melanoma. Melanoma Res. 2009, 19, 185-192.

174. Eisen, T.; Thatcher, N.; Leyvraz, S.; Miller, W.H.; Couture, F.; Lorigan, P.; Luthi, F.; Small, D.; Tanovic, A.; O'Brien, M. Phase II study of weekly plitidepsin as second-line therapy for small cell lung cancer. Lung Cancer 2009, 64, 60-65.

175. Peschel, C.; Hartmann, J.T.; Schmittel, A.; Bokemeyer, C.; Schneller, F.; Keilholz, U.; Buchheidt, D.; Millan, S.; Izquierdo, M.A.; Hofheinz, R.D. Phase II study of plitidepsin in pretreated patients with locally advanced or metastatic non-small cell lung cancer. Lung Cancer 2008, 60, 374-380.

176. Ribrag, V.; Caballero, D.; Ferme, C.; Zucca, E.; Arranz, R.; Briones, J.; Gisselbrecht, C.; Salles, G.; Gianni, A.M.; Gomez, H.; et al. Multicenter phase II study of plitidepsin in patients with relapsed/refractory non-Hodgkin's lymphoma. Haematologica 2012, 98, 357-363.

177. Mateos, M.V.; Cibeira, M.T.; Richardson, P.G.; Prosper, F.; Oriol, A.; de la Rubia, J.; Lahuerta, J.J.; Garcia-Sanz, R.; Extremera, S.; Szyldergemajn, S.; et al. Phase II clinical and pharmacokinetic study of plitidepsin 3-hour infusion every two weeks alone or with dexamethasone in relapsed and refractory multiple myeloma. Clin. Cancer Res. 2010, 16, 3260-3269.

178. Mitsiades, C.S.; Hideshima, T.; Chauhan, D.; McMillin, D.W.; Klippel, S.; Laubach, J.P.; Munshi, N.C.; Anderson, K.C.; Richardson, P.G. Emerging treatments for multiple myeloma: Beyond immunomodulatory drugs and bortezomib. Semin. Hematol. 2009, 46, 166-175.

179. Millward, M.; Price, T.; Townsend, A.; Sweeney, C.; Spencer, A.; Sukumaran, S.; Longenecker, A.; Lee, L.; Lay, A.; Sharma, G.; et al. Phase 1 clinical trial of the novel proteasome inhibitor marizomib with the histone deacetylase inhibitor vorinostat in patients with melanoma, pancreatic and lung cancer based on in vitro assessments of the combination. Invest. New Drugs 2012, 30, 2303-2317.

180. Hamlin, P.A.; Aghajanian, C.; Younes, A.; Hong, D.S.; Palladino, M.A.; Longenecker, A.M.; Lloyd, G.K.; Hannah, A.L.; Spear, M.A.; Kurzrock, R. First-in-human phase I study of the novel structure proteasome inhibitor NPI-0052. J. Clin. Oncol. 2009, 27, 3516.

181. Hofmeister, C.C.; Richardson, P.; Zimmerman, T.; Spear, M.A.; Palladino, M.A.; Longenecker, A.M.; Cropp, G.F.; Lloyd, G.K.; Hannah, A.L.; Anderson, K. Clinical trial of the novel structure proteasome inhibitor NPI-0052 in patients with relapsed and relapsed/refractory multiple myeloma (r/r MM). J. Clin. Oncol. 2009, 27, 8505.

182. Richardson, P.; Hofmeister, C.C.; Zimmerman, T.M.; Chanan-Khan, A.A.; Spear, M.A.; Palladino, M.A.; Longenecker, A.M.; Cropp, G.; Lloyd, G.K.; Wear, S.; et al. Phase 1 clinical trial of NPI-0052, a novel proteasome inhibitor in patients with multiple myeloma. Blood 2008, 112, 955-956. 
183. Lawasut, P.; Chauhan, D.; Laubach, J.; Hayes, C.; Fabre, C.; Maglio, M.; Mitsiades, C.; Hideshima, T.; Anderson, K.C.; Richardson, P.G. New proteasome inhibitors in myeloma. Curr. Hematol. Malig. Rep. 2012, 7, 258-266.

184. Mita, M.M.; Spear, M.A.; Yee, L.K.; Mita, A.C.; Heath, E.I.; Papadopoulos, K.P.; Federico, K.C.; Reich, S.D.; Romero, O.; Malburg, L.; et al. Phase 1 first-in-human trial of the vascular disrupting agent plinabulin(NPI-2358) in patients with solid tumors or lymphomas. Clin. Cancer Res. 2010, 16, 5892-5899.

(C) 2013 by the authors; licensee MDPI, Basel, Switzerland. This article is an open access article distributed under the terms and conditions of the Creative Commons Attribution license (http://creativecommons.org/licenses/by/3.0/). 